\title{
Europos Sajungos bendroji užsienio ir saugumo politika ir Lietuva
}

\begin{abstract}
Nuo pat Maastrichto sutarties stagnavusią ir Balkanuose nesèkmę patyrusią ES bendrają užsienio ir saugumo politiką (BUSP) vẻl išjudino kontraversiškas karas Irake. BUSP kūrimas iggyja vis didesni pagreitị: ES netrukus gali turèti jau ne tik bendrają rinką, bendras institucijas ir viena valiuta, bet ir bendrą konstitucija, užsienio reikalu ministrą ir net bendrą kariuomenę. Ypač entuziastingai už vieningesnę ir stipresnę BUSP pasisako didžiujų ES valstybiu lyderiai, siekiantys didesnès autonomijos nuo JAV sprendimų tarptautinio saugumo srityje. Šio straipsnio autoriai teigia, jog aiškiai artikuliuota ir globaliai projektuojama ES užsienio ir saugumo politika nebus įmanoma tol, kol neatsiras bendru visaeuropinių interesų, paremtų bendru vienos ir vieningos Europos identitetu ir igyvendinamų bendrų viršnacionalinių institucijų. BUSP įtaka Lietuvos užsienio ir saugumo politikai priklausys nuo Europos integracijos šioje srityje spartos ir nuo europinio identiteto stiprumo tarp Lietuvos politinio elito ir pačioje visuomenèje. Kiek ši įtaka bus teigiama, priklausys nuo to, kokiu keliu pasuks pati Europa - savarankiškos gynybinès struktūros, kaip alternatyvos NATO, kūrimo ar glaudžios strateginès partnerystès su JAV ir NATO plètojimo keliu. Bet kokiu atveju jau dabar aišku, jog Lietuvai reikès nuolat ieškoti subtilaus balanso tarp îsipareigojimų NATO, iš narystès ES kylančio poveikio ir glaudžios partnerystės su JAV. Šiame procese Lietuvai labiausiai reikès ne tik ịspūdingo ekonomikos augimo tempo ar modernių karinių pajëgumų, bet ypač diplomatinių sugebejimų lanksčiai manevruoti tarp transatlantinių santykių rifų ginant nacionalinius Lietuvos interesus.
\end{abstract}

\section{Ivadas}

Paprastas ir kartu genialus J. Monnet ir R. Schuman planas sujungti amžinų priešų - Vokietijos ir Prancūzijos - anglies bei plieno pramonę 6-ojo dešimtmečio pr. pradejjo ambicingą Europos integracijos projektą. Sis projektas, turëjęs užkirsti kelią naujam karui tarp minètų valstybių, peraugo į 15 Europos valstybių ekonominę ir politinę sajungą. Nepaisant daugiau nei 50 metų vykstančios sėkmingos ekonominès integracijos, atvedusios ị bendrają rinką, bendrą valiutą ir viršvalstybines valdymo institucijas, Europos Bendrijos, o vèliau Europos Sajungos (toliau-ES) pasieki-

"Doc., dr. Algirdas Gricius - Vilniaus universiteto Tarptautinių santykių ir politikos mokslų instituto docentas. Adresas: Vokiečiu 10, 01130 Vilnius, tel. 8-5-2514130, e-paštas: algirdas.gricius@lrs.lt "Kęstutis Paulauskas - Lietuvos karo akademijos Politikos mokslų katedros déstytojas ir Vilniaus universiteto ir Tarptautinių santykių ir politikos mokslų instituto doktorantas. Adresas: Šilo 5a, 10322 Vilnius, tel. 8-5-2103569, e-paštas: kestutis.paulauskas@pastas.kam.lt 
mai užsienio ir saugumo politikos srityje buvo ir tebėa itin kuklūs, o keletu atvejų patyrè visišką nesėkmę.

2002 m. gruodį Kopenhagoje Lietuva buvo pakviesta tapti ES nare nuo 2003 m. gegužès 1 d. Kokia bus išsiplètusios ES užsienio politika? Kaip būsima narystė paveiks Lietuvos saugumo politiką, iki šiol balansavusią tarp paramos NATO lyderei JAV ir paramos ES, kurių požiūriai kartais nesutapdavo ir nesutampa net dèl esminių tarptautinio saugumo klausimų, kaip Irako nuginklavimas ar Tarptautinio baudžiamojo tribunolo veikla? Vien Lietuvoje apie eurointegracijos istoriją, ekonominę sajungą, bendrają užsienio ir saugumo politiką, ES institucijas ir veikimo mechanizmą jau yra parašyta daugybẻ knygų, studijų ir straipsnių. Naujausi darbai šia tema-K. Manioko studija „Europos Sajungos plètra ir europeizacija: Vidurio ir Rytų Europos valstybių įsijungimas į Europos Sajungą" ; E. Vareikio „Dinozaurejjanti Europa“2, R. Vilpišausko „Integracija Europoje: Baltijos šalys ir Europos Sajunga“"3 . Apie įvairius ES integracijos aspektus yra rašę ir šio straipsnio autoriai ${ }^{4}$.

Nepaisant literatūros gausos, daugelis teorinių ir empirinių problemų lieka neišspręstos. Pagaliau sunkiai prognozuojamoje tarptautinejje saugumo aplinkoje ES ir jos narių politika yra itin dinamiškas ir todèl neišsemiamas akademinių tyrinejjimų objektas. Naujausia tokių tyrinẻjimų medžiaga $-2003 \mathrm{~m}$. liepos mèn. pasibaigusio Konvento dẻl Europos ateities darbo rezultatai. Pusantrų metų trukusi diskusija, kurioje kartu su ES parlamento bei Komisijos atstovais dalyvavo ir ES valstybių narių ir šalių kandidačių nacionalinių parlamentų bei vyriausybių atstovai, baigèsi Europos Sajungos Konstitucinès sutarties projekto ${ }^{5}$ parengimu. Projekte greta ženklių pokyčiu ES institucijų veikloje numatomi ir gana reikšmingi saugumo ir gynybos politikos pasikeitimai. Konstitucinès sutarties projektą dar turi patvirtinti $2003 \mathrm{~m}$. rudenį prasidèsianti Tarpvyriausybinè konferencija, kuri, be abejonès, gali net ir iš esmès revizuoti minètus pokyčius. Būsimos Lietuvos narystės ES kontekste visi šie klausimai įgyja papildomą prasmę ir aktualumą.

Šio straipsnio autoriai siekia dviejų tikslų. Pirma, paaiškinti, kodėl, nepaisant sèkmingos ekonominès integracijos, ES iki šiol nesugeba tokios integracijos pasiekti užsienio politikos srityje ir, tapusi ekonomikos milžine, tebėra nykštukẻ tarptautinio saugumo prasme. Antras klausimas empiriškesnis: kokia yra ir kokia turètų būti ateityje Lietuvos saugumo politika ES bendrosios užsienio ir saugumo politikos atžvilgiu (BUSP): besąlygiška parama BUSP (proeuropietiška politika), balansavimas tarp ES ir NATO bei kompromisų ieškojimas (politika, orientuota ị transatlantinio ryšio stiprinimą) ar visiškas BUSP ignoravimas (atlantistinè arba proamerikietiška pozicija).

\footnotetext{
${ }^{1}$ Maniokas K., Europos Sajungos pletra ir europeizacija: Vidurio ir Rytu Europos valstybiu įsijungimas $i$ Europos Sajunga, Vilnius: Eugrimas, 2003.

2 Vareikis E., Dinozaurejanti Europa, Vilnius: Strofa, 2002.

${ }^{3}$ Vilpišauskas R., Integracija Europoje: Baltijos šalys ir Europos Sajunga, Vilnius: Arlila, 2001.

${ }^{4}$ Gricius A., „Europos Sajungos plètros problemos“ žr. Europos Sajunga: institucinè saranga ir politikos aktualijos, Vilnius: Eugrimas, 2000, p. 7-19; Paulauskas K., „Europos gynybos politika po St. Malo deklaracijos“, Krašto apsauga, Nr. 4 (7), 2002, p. 7-11.

${ }^{5}$ Draft treaty establishing a Constitution for Europe, submitted to the European Council meeting in Thessaloniki - 20 June 2003, Luxemburg: Office for Official Publications of the European Communities, 2003, VIII, 161 p.
} 
Pagrindinè šio straipsnio autorių prielaida yra ta, jog aiškiai artikuliuota ir globaliai projektuojama ES užsienio ir saugumo politika nebus įmanoma tol, kol neatsiras bendrų visaeuropinių interesų, paremtų bendru vienos ir vieningos Europos identitetu ir ịgyvendinamų bendrų viršnacionalinių institucijų. Atitinkamai BUSP itaka Lietuvos saugumo politikai priklausys nuo Europos integracijos šioje srityje spartos ir nuo europinio identiteto stiprumo tarp Lietuvos politinio elito ir visuomenés narių. Toliau straipsnyje aptariami teoriniai ES integracijos BUSP srityje rèmai.

\section{Europos saugumo identiteto problema}

İvairios tarptautinių santykių teorijos ịvairiai bando aiškinti ES integracijos fenomeną, suteikdamos skirtingą reikšmę ir svorị trims minètiems kintamiesiems: identitetui, institucijoms ir interesams, tačiau, kai kurių autorių teigimu, šie bandymai dažniausiai yra nesèkmingi ${ }^{6}$. Iš tikrujų skirtingos tarptautinių santykių teorijos gana sėkmingai gali paaiškinti atskirus ES integracijos fenomeno aspektus: ekonominę naudą, socialinę gerovę, taiką ar saugumą, tačiau fenomeno visumai aprépti ir paaiškinti jau reikia ieškoti šių teorijų sintezès galimybių.

\subsection{Europos integracija ir tarptautinių santykiụ teorijos}

Šaltojo karo metais dominavusiai realistinei paradigmai Europos integracija tapo milžinišku iššūkiu, kadangi ji iš esmès prieštaravo realizmo apologetų prielaidoms. Pavyzdžiui, vienas ryškiausių realistų K. Waltz teigè, jog ekonominis bendradarbiavimas lemia tarpusavio priklausomybę, kuri kelia grèsmę valstybių nacionaliniam saugumui ${ }^{7}$, todèl valstybės, kaip racionalūs veikèjai, siekiantys aiškių nacionalinių interesų, turètų vengti tokios priklausomybės. Eurointegracijos realybẻ iš esmės paneigé šias prielaidas: Europos valstybės ne tik išplète ekonominį bendradarbiavimą iki bendros rinkos, bet ir delegavo dalį savo nacionalinio suvereniteto viršnacionalinems institucijoms. Taigi Europos integracija tapo pagrindiniu liberalizmo paradigmos tyrinèjimų objektu ${ }^{8}$. Pagal šią paradigmą valstybès nèra vienintelès tarptautinių santykių veikèjos - tarptautinès organizacijos yra ne mažiau svarbios. Dar daugiau - ekonominis bendradarbiavimas tarp ilgus amžius kariavusių Europos valstybių ne tik nepakenkẻ jų saugumui, bet ir tapo esmine ilgalaikès taikos Europoje sąlyga.

Vis dèlto liberalizmo paradigmos prielaidos negali paaiškinti, kodẻl sékminga Europos valstybių ekonominè integracija nelèmè politinès gynybinès integracijos. Juk jeigu ekonominè tarpusavio priklausomybè iki minimumo sumažino karo tikimybę tarp ES narių, bendra užsienio ir saugumo politika leistų geriau apsiginti ir nuo išorinių iššūkių bei užtikrinti ir apsaugoti ES interesus pasaulyje. Tam tikra prasme ši

${ }^{6}$ Žr.: Kelstrup M., Williams M. C. (red.), International Relations Theory and the Politics of European Integration: Power, Security and Community, London: Routledge, 2000, p. 3.

${ }^{7}$ Žr.: Waltz K., Theory of International Politics, New York: McGraw-Hill, 1979.

${ }^{8}$ Liberaliai tarptautinių santykiu tradicijai galima priskirti tokius darbus: McCormick M., The European Union: Politics and Policies, Oxford: Westview Press, 1999; Slomp H., European Politics into the 21st Century, Westport: Praeger Publishers, 2000; Kotlowski J. D. (red.), The European Union: From Jean Monnet to the Euro, Athens: Ohio University Press, 2000. 
fenomeną gali geriau paaiškinti realistai, teigiantys, jog nacionalinis saugumas yra svarbiausias valstybės atributas, aukščiausia jos suvereniteto išraiška, todėl ypač didžiosios valstybès nenori išsižadèti savo istorinès prerogatyvos užsienio ir saugumo politikos srityje bendrų ES interesų labui.

Liberalizmo paradigma sẻkmingai gali paaiškinti ekonominę integraciją, o realistinè paradigma gali padèti atskleisti, kodèl panaši integracija nevyko užsienio ir saugumo reikaluose, tačiau nei viena, nei kita paradigma nesugebejo sujungti abieju tendencijų i vieną nuoseklią integracijos teoriją.

Kai kurių autorių teigimu, postpozityvistinis socialinis konstruktyvizmas gali pasiūlyti geresnį Europos integracijos aiškinimą ${ }^{9}$ nei racionalistinès realistų ir liberalų teorijos. Konstruktyvistų teigimu, ,materialinès struktūros turi prasmę tik tam tikrame socialiniame kontekste, per kuri jas galima interpretuoti ${ }^{\text {“10 }}$. Kitaip tariant, negalima ES suprasti vien kaip tarptautinès organizacijos atliekančios tam tikras valstybių nariu jai pavestas funkcijas, bet būtina turèti omeny daugelį socialinių veiksnių: Europos istoriją, geografiją, normas, vertybes ir net idejas, veikiančias ir formuojančias europiečių mąstymą. Pozityvistinès realizmo ir liberalizmo paradigmos pernelyg suprastina socialinę tikrovę, būtent todèl racionalistiniai aiškinimo modeliai negali atskleisti šiu mažiau racionalių, bet itin svarbių faktorių poveikio ES ir jos narių politikai.

Pagaliau labai svarbus konstruktyvizmo požiūriu kintamasis yra tarptautinių santykių subjekto identitetas, kuris didžiaja dalimi sąlygoja ir jo interesus bei preferencijas ${ }^{11}$. Kitaip tariant, kalbant apie Europos Sajungą žodis Europa yra ne mažiau svarbus už žodị Sajunga, analogiškai žodžiuose „Amerikos hegemonija“ Amerika yra ne mažiau svarbu už hegemoniją. Identitetas yra apriorinė vertybinè ir norminė konstrukcija, pagal specifines politines, socialines, kultūrines ir kitokias kokybines savybes išskirianti tarptautinių santykių veikejją iš kitų subjektų. Taigi egzistuoja kokybinis skirtumas tarp tokių sąvokų kaip „Europos Sajunga“ ir „,Sovietų Sajunga“ arba „Amerikos hegemonija“ ir „Europos hegemonija“.

Nors šio straipsnio autoriai nėra linkę nuvertinti tradicinių tarptautinių santykių teorijų koncepcijų, kaip suverenitetas, nacionalinis saugumas ar galia, vis dèlto, nagrinėdami dabartinę ES BUSP, autoriai atsižvelgia į̌sias pakankamai naujas ir svarbias ị̌̌valgas apie pačios ES socialinės prigimties ypatumus ir jų pasekmes Lietuvos saugumo politikai.

\subsection{Viena Europa ar daug Europų?}

Kas yra Europa? Būtų klaidinga teigti, jog Europa neturi identiteto. Greičiau atvirkščiai - Europa turi labai daug identitetų. Galima brèžti skirtingus, bet tarpusavyje glaudžiai susijusius Europos tapatybės žemėlapius: politinį, geografinį, saugumo, ekonominị, kultūrinị ar religinị ${ }^{12}$.

${ }^{9}$ Žr. Smith S., „International Theory and European Integration“ in Kelstrup M., Williams C. M. (red.), (note 6) p. 48.

${ }^{10} \mathrm{Z} r$.: Checkel J. T., „The Constructivist Turn in International Relations Theory“ in World Politics, 50 (2).

${ }_{11}$ Žr. Ruggie J. G., What Makes the World Hang Together? Neo-utilitarianism and the Social Constructivist Challenge, International Organization, 52 (4).

12 Plačiau apie Europos „mentalinius žemèlapius“ žr.: Walker M., „Variable geography: America’s mental maps of a Greater Europe“, International Affairs, Vol. 76, No. 3, 2000, p. 459-475. 
Bene paprasčiausias yra politinis Europos žemèlapis - tai daugiau nei 40 ịvairaus dydžio valstybių nuo nykštukinių Maltos ir Lichtenšteino iki Prancūzijos ir Vokietijos. Iš šių 40 valstybių 15 yra ES narès, o dar 10 ES narėmis taps $2004 \mathrm{~m}$. Etniniu požiūriu tai daugiau nei 100 etninių bendrijų ${ }^{13}$. Geografiniu požiūriu Europos ribos paprastai brèžiamos apie Viduržemio jūrą pietuose, Atlanto vandenyną vakaruose, Arkties vandenyną šiaurẻje ir Uralo kalnus rytuose, todèl ị europiečių varda gali pretenduoti Rusija, Ukraina, Turkija ir net Gruzija. Apie 270 mln. gyventojų (be 150 mln. rusų) gyvena Europoje, bet ne ES, taigi būtų klaidinga visiškai tapatinti ES su Europa. Nei kultūriniu, nei religiniu požiūriu Europa taip pat nèra homogeniška. Europiečiai kalba 36 kalbomis $^{14}$ (be tarmių ir dialektų), Europoje gyvena katalikai, protestantai, pravoslavai ir musulmonai.

Dar komplikuotesnis yra Europos saugumo žemėlapis. Tokiose euroatlantinio saugumo organizacijose kaip Euroatlantinès partnerystės taryba (EAPT) ar Europos saugumo ir bendradarbiavimo organizacija (ESBO), dalyvauja daugiau nei 50 Europos, Kaukazo, Vidurio Azijos valstybių bei JAV ir Kanada. NATO ir ES vykdo sparčią plètrą į Vidurio ir Rytų bei Pietų Europą. Net Ukraina, Azerbaidžanas ir Gruzija kalba apie tolimą narystės perspektyvą, o Maroko karalius yra kẻęs net Maroko narystės ES klausimą ${ }^{15}$. Kyla klausimas, kiek dar plèsis ES ir NATO ir ar narystė šiose organizacijose galiausiai apibrěš išorines Europos sienas.

Europos identiteto apibrèžimas priklauso ir nuo to, iš kokios perspektyvos ị Europą žiūrima. Šaltojo karo metais sąvokos „Vakarai“ ir „Europa“ buvo vartojamos kaip sinonimai, nors NATO ( t. y. „Vakarams“) priklause Graikija ir Turkija (pietryčiu Europa), o Čekoslovakija buvo „Rytuose“. Kandidatuojantis į ES Kipras yra tik $200 \mathrm{~km}$. nuo Libano kranto, nutolęs labiau ị pietus nei Tunisas ar Alžyras ir labiau ị rytus nei Kijevas. Prancūzijos prezidentas De Gaulle turëjo „tam tikrą Europos idèją "16 ir ịsivaizdavo Europą kaip politinę suverenių valstybiu sąungą nuo Atlanto iki Uralo. NATO požiūriu Europa faktiškai apima erdvę nuo Vankuverio iki Vladivostoko (plg. ES požiūrị: Europa nuo Lisabonos iki Liublianos) ${ }^{17}$ : PfP pratybos jau rengtos ir Kazachstane, o tai jau Vidurinė Azija. Taigi „Europa“ žiūrint iš Vašingtono atrodo daug didesné nei „Europa“, matoma pro Briuselio langus. Galima būtų spekuliuoti, jog NATO plètra į VRE šalis iš viso nebūtų vykusi, jeigu JAV būtų palikusi iniciatyvą patiems europiečiams, tačiau sparti NATO plètra privertẻ eurobiurokratus paspartinti ir ES plètrą. Taigi bet koks Europos apibrěžimas yra neišvengiamai subjektyvus ir priklauso nuo istorinès, kultūrinès ir politinės perspektyvos.

Dabartinė Irako krizė tik dar kartą patvirtino, jog šiuo metu nęimanoma kalbẻti apie kokị nors politini vieningos Europos identitetą po ES vẻliava. Netgi imta kalbėti apie naują Europos skilimą, tik šįkart į Senają Europą - Prancūziją ir Vokietiją, priešinančias save Amerikai, ir transatlantinę Naujają Europą ${ }^{18}$, remiančią JAV poziciją.

\footnotetext{
${ }_{13}$ Žr.: McCormick M., (note 8) p. 92.

${ }^{14}$ Ten pat.

${ }^{15}$ Wallace W., ,From the Atlantic to the Bug, from the Arctic to the Tigris? The Transformation of the EU and NATO“, International Affairs, Vol. 76, No. 3, 2000, p. 477.

${ }^{16}$ Apie De Gaulle Europos vizija plačiau žr.: Bozo F., Two Strategies for Europe: De Gaulle, the

United States, and the Atlantic Alliance, Oxford: Rowman and Little Publishers, Inc., 2001.

${ }_{17}$ Walker M., (note 12) p. 452.

${ }^{18}$ Pavyzdžiui, žr.: „New Europe, Old Europe“, Wall Street Journal, 24 Jan. 2003.
} 
Kita vertus, turint omeny didžiulę politinę ir kultūrinę įvairovę, kelis šimtmečius karu, draskiusiu visą Europos kontinentą, pasiektas Europos integracijos lygis yra neįtikètinas. Tokie Europos vienybės simboliai, kaip ES vẻliava, himnas (L. W. Bethoven „Odė džiaugsmui“), bendra valiuta ir galiausiai kuriama ES Konstitucija byloja bent jau apie besiformuojantị vieningos Europos identitetą. Pagaliau kaip pabrèžia M. McCormick, bendro Europos identiteto formavimasis priklauso nuo pačiu europiečių, nuo to, kaip jie supranta Europos Sajungą ir kaip greitai jiems pavyks ịveikti istorinius mitus bei užmiršti kelis šimtamečius vykusių karų praeiț̨ ${ }^{19}$. Pagal naujausias Eurobarometro apklausas, daugiau nei $50 \%$ ES šalių gyventojų jaučiasi esą ne tik vokiečiai, italai ar norvegai, bet ir europiečiai, $10 \%$ jaučiasi esą tik europiečiai $^{20}$. Didejant taip mąstančių Europos gyventojų proporcijai, kitas žingsnis jau būtų tikra Europos pilietybè.

Apibendrinant galima teigti, jog, viena vertus, sunku įsivaizduoti bendrą ES užsienio ir saugumo politiką nesant aiškiai apibrèžiamo Europos kaip tokios identiteto. Kita vertus, patį Europos identitetą geriausiai apibūdina įvairovè ir pliuralizmas, o ne vienovè, todèl vargu ar galima tikètis, jog ES kada nors tarptautiniuose santykiuose imtu veikti kaip viena ir vieninga nacionalinè valstybė. Pagaliau kalbant apie ES identitetą tradicinių tarptautinių santykių paradigmų retorika nebera pakankama, kaip ir teigia konstruktyvistai,--socialinè tikrovė yra kur kas sudètingesnė nei santykiai tarp nacionalinių valstybių ir tarptautinių organizacijų.

\subsection{Lietuvos europinis identitetas}

Kaip reiškiasi europinio identiteto sklaida Lietuvoje? Po nepriklausomybės atkūrimo savotiškas Lietuvos užsienio politikos credo buvo grižimas į Europą. 2003 m. gegužès 10-11 d. îvykusiame referendume net devyni iš dešimties balsuoti atèjusių Lietuvos piliečių pasisakẻ už narystę ES,o proeuropietiškiausia Baltijos valstybe laikytoje Estijoje už narystę balsavo tik $63 \%$ rinkèjų.

Kyla klausimas, ar toks Lietuvos visuomenès troškimas tapti ES nare kilo todèl, kad lietuviai jaučiasi europiečiais, ar todèl, kad tikisi politikų rožinių pažadų išsipildymo? Būtų naivu manyti, kad kitų ES šalių piliečiai pasisakè už prisijungimą prie ES vien iš europietiško solidarumo. Kita vertus, galima klausti, kas iš tikrųų sudaro europietiškos tapatybės turinị. Ar tai bendra istorija, kurioje daugiau karų, nacionalizmo ir ksenofobijos; ar kultūra ir kalba, kuriose daugiau skirtumų nei panašumų; gal tai ES simboliai - vèliava, himnas, euras ir ES piliečio pasas, kurie kelia mažiau emocijų nei atitinkami nacionaliniai simboliai? Galbūt ES siejama su socialine gerove ir saugumu, laisve keliauti, dirbti ir plètoti verslą bet kurioje šalyje? Matyt, teisingiausias atsakymas būtų ir viena, ir kita, kadangi pirma galiausiai sąlygojo antra ${ }^{21}$.

Šiandien turbūt jau niekas neginčija ir Lietuvos geografinès, istorinès, kultūrinès ir tam tikra prasme moralinès priklausomybès Europai. Konstitucinè sąranga,

${ }^{19}$ Žr.: McCormick M., (note 8) p. 73.

${ }^{20}$ Žr.: European Commission: Eurobarometer 57: Public Opinion in the European Union, 2002, http://europa.eu.int/comm/public_opinion/archives/ eb/eb57/eb57_en.pdf.

${ }^{21}$ Vienas įdomiausių darbų, visapusiškai nagrinèjančių ES tapatybēs problematiką, yra Delanty G., Europos išradimas: ideja, tapatumas, realybè, Vilnius: Lietuvos rašytojų sajungos leidykla, 2002. 
institucijos, teisinè sistema Lietuvoje buvo kuriama remiantis Europos valstybių patirtimi. Be abejonès, Lietuvos europeizacijai didžiausią įtaką padarè ir tebedaro pats eurointegracijos procesas, ES iškelti reikalavimai narystei ir Lietuvos pasirengimas $j^{22} .2004$ m. gegužès 1 d. Lietuva papildys politinį ES žemèlapį kaip visavertè šios organizacijos narè.

Daug painesnis yra regioninis Lietuvos identiteto lygmuo: Lietuva yra piečiausia Šiaurès Europos regiono šalis ir šiauriausia Vidurio Europos valstybè. Lietuva taip pat yra ir Baltijos jūros regiono valstybè. Priklausomybè vienam ar kitam regionui suponuoja gana skirtingus Lietuvos užsienio ir saugumo politikos aspektus. Lietuvos buvimas Šiaurès Europoje visų pirma reiškiasi per gana išplètotą politinio, ekonominio, kultūinio ir karinio bendradarbiavimo formatą 5 (Skandinavijos valstybès) +3 (Baltijos valstybės). Lietuvą VRE regiono kontekste galima traktuoti kaip vieną iš lyderių, ypač dèl sẻkmingos Vilniaus-10 grupès veiklos koordinuojant regiono šalių pasirengimą narystei NATO. Pagaliau Baltijos jūros regionas yra institucionalizuota Baltijos jūros valstybių tarybos (BJVT) pagalba ir, be trijų Baltijos valstybių, apima Suomiją, Švediją, Daniją, Lenkiją, Rusiją, Vokietiją bei sprendžia ekonominius, socialinius, ekologinius regioninio bendradarbiavimo klausimus.

Lietuvos saugumo identiteto turinys ir jo europinè dimensija yra bene kontraversiškiausia. Paradoksalu, bet bene didžiausią įtaką Lietuvos saugumo politikai daro išorès, o ne europinis veiksnys - santykiai su JAV: JAV vaidmens negalima nepaisyti kalbant apie Lietuvos saugumo identitetą, ypač jos narystės NATO kontekste. Šis vaidmuo, ilgai buvęs neformalus, buvo įtvirtintas $1999 \mathrm{~m}$. pasirašyta JAV ir triju Baltijos valstybių chartija. Šio dešimtmečio pradžioje bendradarbiavimas igyja platesni $-5+3+1$ formatą, kurio pagrindiniai tikslai yra JAV dèmesio išlaikymas Šiaurès rytų Europos erdvei ir pastangų plèsti saugumo erdvę toliau ị rytus koordinavimas. Nors, kai kurių Lietuvos autorių teigimu, JAV reikšmė Lietuvos užsienio politikai buvo ir tebėra pernelyg sureikšminama, o didžiujų ES valstybių, ypač Vokietijos, vertinama nepakankamai ${ }^{23}$, šio straipsnio autorių nuomone, vien buvimas Europoje neturètų būti lemiamu veiksniu Lietuvai nustatant savo užsienio ir saugumo politikos prioritetus. Šiuos prioritetus turi lemti ne sentimentai vienai ar kitai šaliai, bet objektyvūs geostrateginiai veiksniai. Galima būtų netgi kelti tokị retorinị provokacinį klausimą: kas pirmas ateitų Lietuvai į pagalbą agresijos atveju - Prancūzija ir Vokietija ar JAV?

Apibendrinant galima teigti, jog Lietuvos europinis identitetas dar nèra visiškai išsikristalizavęs. Taip pat reiktų pastebėti, jog europinis identitetas nèra vienodai stiprus skirtingose srityse: kalbant apie istoriją, kultūrą, teisinę sistemą ir vertybes, Lietuvoje jau galima stebėti gana ryškią europietiškos savimonès ir mentaliteto sklaidą, bet apie saugumo politiką to paties dar negalima sakyti.

\footnotetext{
${ }^{22}$ Lietuvos europeizacijos fenomeną išsamiai nagrinejja $\mathrm{K}$. Maniokas, (note 1).

${ }^{23}$ Pvz., žr.: Nekrašas E., „NATO ir Europos Sajungos santykių transformacija bei Lietuvos užsienio politika“ žr.: Siaurés Atlanto erdvé ir Lietuva, Vilnius: Eugrimas, 2001, p. 35.
} 


\section{ES vaidmuo pasaulyje}

Besiformuojantis ES, kaip pliuralistinès europietiškos bendruomenès, identitetas yra, be abejonės, svarbus veiksnys, lemiantis ES išskirtinumą ir tam tikra prasme apibrėžiantis jos vietą pasaulyje. Vis dẻlto vieno ar kito tarptautinès sistemos subjekto tapatybės nustatymo nepakanka jo išorinių santykių praktikai paaiškinti. Kitaip tariant, ES vaidmenị ir galios sklaidą pasaulyje lemia kiti du kintamieji - interesai ir juc igyvendinimo instrumentai: institucijos bei atitinkami ekonominiai, demografiniai, kariniai resursai.

\subsection{ES interesai: bendro vardiklio problema}

Kitas ES vaidmenị pasaulyje sąlygojantis elementas - interesai. Kad ir koks sunkiai apčiuopiamas Europos identitetas, vis dẻlto visas ES valstybes vienija vienas dalykas - jos visos yra Europoje. Pagaliau tai esminis ES narystės kriterijus šalia demokratijos ir rinkos ekonomikos. Be bendro identiteto, apskritai nebūtų i̇manoma kalbėti apie kokius nors bendrus interesus. Todèl vien pats buvimas Europos kontinente tampa savotišku mažiausiu bendru vardikliu bendriems interesams atsirasti.

Vis dèlto tenka pastebėti, jog konstruktyvistinè tarptautinių santykių interpretacija turi tam tikrą trūkumą: aiškindami visumos, socialinio tarptautinès sistemos audinio svarbą, konstruktyvistai paprastai pamiršta pačius šios sistemos veikejjus valstybes ir tarptautines organizacijas. Būtent šių veikèjų preferencijos, motyvai, intencijos, interesai konstruoja socialinę tikrovę, o ne atvirkščiai, nors tam tikras grįžtamasis ryšys ir egzistuoja. Žinoma, svarbu tai, jog, pavyzdžiui, ES didelį prioritetą teikia humanitarinei pagalbai daugiausia dèl to, kad tai yra kone organiška Europos identiteto dalis ir to iš jos tikisi partnerès. Kitas dalykas, kaip šis interesas yra igyvendinamas ir kaip jis lemia veikejų tarpusavio santykius, o tai jau politikos klausimas, kurį sprendžiant identiteto klausimas nebėra svarbiausias.

Pati Europos integracija prasidejo nuo bendro intereso - išvengti dar vieno karo tarp Prancūzijos ir Vokietijos, dar vienas svarbus bendras Europos tikslas išvengti Sovietų Sajungos grèsmès. Kitaip tariant, Europos integracijos pradžioje bendrasis vardiklis valstybių interesų prasme buvo gana aukštas, tačiau po Šaltojo karo išnyko buvęs aktualiausias dalykas - sovietų agresijos baimė. Taigi valstybių nacionalinių interesų spektras ir įvairovẻ labai išsiplètè, tad interesai ne tik dažnai nesutapo, bet ir prieštaravo vieni kitiems, todèl bendrasis ES vardiklis smarkiai sumažèjo. Vis dẻlto klaidinga būtų manyti, jog Europos šalys nebeturi bendrų tikslų, netgi atvirkščiai: augančiai ES ekonominei galiai paremti ir globaliniams interesams apsaugoti kaip niekada iki šiol yra būtinas vieningas politinis veikimas tarptautinėje arenoje. Būtent šị supratimą ir ịkūnijo dar Maastrichto sutartyje numatyta BUSP. Šios sutarties J.1 straipsnyje išdėstyti BUSP tikslai savotiškai ir atspindi tai, ką būtų galima vadinti ES bendrais interesais:

- saugoti bendrai puoselëjamas vertybes, esminius sajungos tikslus ir jos nepriklausomybę;

- visais būdais stiprinti ES ir atskirų jos šalių saugumą;

- užtikrinti taiką, stiprinti tarptautinị saugumą; 
- skatinti tarptautinį bendradarbiavimą;

- plètoti bei stiprinti demokratiją, pagarbą žmogaus teisèms ir laisvèms.

Vargu ar kuri nors ES valstybẻ pasisakytų prieš, pavyzdžiui, tarptautinės taikos saugojimą ar tarptautinį bendradarbiavimą. Problemos kyla dèl skirtingo požiūrio ị šių tikslų ịgyvendinimą. Pavyzdžiui, kai ES praejusio dešimtmečio pradžioje bandè spręsti krizę Balkanuose, visos narès iš esmès sutarè, kad pagrindinis ES tikslas yra saugumo ir taikos atstatymas regione, tačiau dauguma šalių skirtingai įsivaizdavo šio siekio ịgyvendinimo strategiją.

\subsection{BUSP ịgyvendinimo galimybès}

Akivaizdu, jog gerų norų nepakanka vieningai BUSP igyvendinti. Tikslų ivykdymo galimybes, taigi ir ES išorès santykių sẻkmę, lemia keli daugiau ar mažiau objektyvūs veiksniai.

Pirmiausia tai Vokietijos ir Prancūzijos ryšio stiprumas, kuris bent šiuo metu abejonių nekelia: jau periodiškai rengiami ir bendri abiejų šalių parlamentų posėdžiai. Paryžiaus ir Berlyno ašis faktiškai buvo ir yra BUSP varomoji jèga, tačiau, kaip parode Irako krizè, ši ašis gali likti be krumpliaračiu, jeigu visiškai neatsižvelgs ị kitų didžiujų ES valstybių, ypač D. Britanijos, Italijos, Ispanijos, nuomonę ir nepaisys būsimų narių saugumo interesų. Pagaliau, be Didžiosios Britanijos, bet kokia nuosekli ES užsienio ir saugumo politika vargu ar yra įmanoma. 1998 m. D. Britanijos ir Prancūzijos ministrų pirmininkų J. Chirac ir T. Blair kartu paskelbta St. Malo deklaracija, kurioje reiškiamas įsitikinimas dẻl Europai būtinos autonomiškos nuo NATO saugumo ir gynybos dimensijos, buvo žingsnis į priekị, tačiau progresą pristabde ir tam tikra prasme pasuko atgal Irako įvykiai. Ittakingojo dienraščio Financial Times ekspertų teigimu, šiandien ES kyla trys problemos: britų, vokiečių ir prancūzų problema $^{24}$. Galima pridurti, jog visos jos yra susijusios ne tik su interesų suderinamumo, bet ir tapatybės problema. Londonas per 30 narystės ES metų tebėra pasiklydęs tarp savo specialaus ryšio su Vašingtonu, atlantizmo ir euroskepticizmo iš vienos pusès ir faktinès priklausomybès ES iš kitos. Prancūzijos politinis elitas vadovaujasi šūkiu: kas blogai Amerikai, tas gerai Prancūzijai. Tą patị šūkị Paryžius bando pritaikyti ir likusiai Europai, todėl natūralu, kad JAV parėmusioms ES kandidatėms J. Chirac pasiūlè patylèti ir todèl sukèlè visuotinị pasipiktinimą VRE sostinėse. Taigi Prancūzijos problema yra ne tiek jos istorinis konfliktas su JAV, kiek bandymas kurti Europos tapatybę antiamerikietiškumo pagrindu, o tai jau savaime destruktyvi strategija, kuri ne tik nedavẻ jokių teigiamų rezultatų, bet dar labiau padidino įtampą tarp senosios ir naujosios Europų. Pagaliau Vokietija, kamuojama istorinių traumų, politinio karinio menkavertiškumo, nerealizuoto lyderystès potencialo, atrodo, niekaip negali atrasti savo tapatybès Europoje ir todèl juntamas blèstantis euroentuziazmas. Financial Times ekspertų receptas Europos vienybei pasiekti - europietiškesnè Didžioji Britanija, kuklesnè Prancūzija ir drąsesnė Vokietija.

${ }^{24}$ Ash T. G., Mertes M., Moisi D., „Only a club of three can bring European unity“, Financial Times, 11 July 2003, p. 11. 
Kitas svarbus veiksnys - politinès krizès ES viduje ir ES gebėjimas jas suvaldyti. BUSP konsensuso principai subyra kaip kortų namelis rimtų krizių atvejais. Taip buvo Balkanuose, kai Vokietija, nepasitarusi su kitomis ES narėmis, pripažino Slovenijos ir Kroatijos nepriklausomybę, o ES pastangos suvaldyti kylančią karo audrą Balkanuose patyre visišką fiasko ir prireike JT bei NATO ịsikišimo. Panašią situaciją galima buvo stebèti ir prieš antraji Persų įlankos karą: vietoj bendros ES pozicijos iš pradžių bendrą laišką parašè 8 Europos valstybès, tada atskirą pareiškimą pateikẻ 10 Vilniaus grupès šalių, o Vokietija, Prancūzija ir Belgija atkakliai laikėsi visiškai priešingos pozicijos. Irako klausimu ES ne tik neturejo bendros politikos, bet ir visiškai nekoordinavo atskirų šalių veiksmų bei demaršų. Būtent tokios krizės ir yra geriausias BUSP vieningumo ir efektyvumo testas. Iki šiol tokio testo ES nè karto nepavyko išlaikyti.

Dar vienas itin reikšmingas faktorius - transatlantiniai santykiai, kurie šiuo metu išgyvena bene didžiausią krizę nuo II pasaulinio karo pabaigos. Iš vienos pusės, JAV po Balkanų ir Kosovo krizių visiškai prarado pasitikẻjimą neveiksminga Europos komitetų komitetèlių sistema (ang. war by committee) ir vis dažniau yra linkusi tarptautinių krizių atvejais imtis vienašališkų veiksmų, paremtų savanoriškomis koalicijomis (ang. coalitions of the willing). Nepamatuotos ES politinès ambicijos ir nenoras atitinkamai investuoti į savo saugumą ir gynybą turejo atvirkštinių pasekmių: Europos sajungininkių įtaka Vašingtonui gerokai sumažèjo JAV sprendžiant tarptautinio saugumo klausimus (karai Afganistane ir Irake). Iš kitos pusès, augantis JAV vienašališ̌kumas paakino kai kurias svarbias NATO sajungininkes Europoje dar labiau atitolti nuo Vašingtono. Antiamerikietiškos Prancūzijos nuotaikos Irako krizès metu nebuvo itin netikètos, bet atkaklaus Vokietijos pasipriešinimo prieš karą Irake ekspertai neprognozavo arba manè, kad jis eventualiai ištirps ir Berlynas prisijungs prie JAV koalicijos. Galima daryti paradoksalią prielaidą, jog ES daugiašališkumo siekiai sprendžiant tarptautines problemas tik sumažino ES galimybes paveikti tų problemų sprendimą.

Pagaliau ne mažiau svarbus veiksnys yra Europos komisijos (EK) vaidmuo ES išorès santykiuose. EK yra efektyviausias ES sprendimų prièmimo ir ịgyvendinimo organas, kadangi jo nevaržo tarpvyriausybiškumo principai. Problema ta, kad EK išorès santykių direktorato, vadovaujamo Ch. Patten, funkcijos apsiriboja išorès ekonominiais bei prekybiniais santykiais, o saugumo ir gynybos reikalai lieka antrosios kolonos - BUSP prerogatyva. Žinoma, EK galètų aktyviau panaudoti savo svorị ES siekiant suvienodinti šalių narių pozicijas ir išreikšti bendrus ES interesus įvairiais pasaulinės politikos klausimais, tačiau nacionalinès vyriausybės akylai stebi, kad EK neviršytų savo ịgaliojimų. Rezultatas - EK daugeliu atveju lieka tik apgailestauti ${ }^{25}$. Tiesa, kai kurios planuojamos institucinės ES reformos, kurios bus aptartos toliau, gali šiek tiek padidinti EK svorị sprendžiant tarptautinius reikalus.

Nepaisant daugelio minètų bendro vardiklio problemų, išorès santykių ekonominejje srityje ES ne tik turi labai aiškius bendrus tikslus, bet neretai ir sèkmingai juos iggyvendina. Kalbant apie ES globalinị vaidmenį, būtent ekonomika yra pagrindinis ES galios šaltinis ir išraiška.

\footnotetext{
${ }^{25}$ Būdingas EK bejëgiškumo pavyzdys: 2003 kovo 18 dieną AFP tarnyba išplatino tokio turinio žinutę: „Europos Komisija santūriai kritikavo JAV ir jụ sajungininkes, atsisakiusias diplomatiniu Irako krizės sprendimo būdų, pareikšdama, kad karinès jëgos naudojimo reikètų išvengti. „Panašu, jog kai kurios šalys netrukus ketina imtis vienašaliu veiksmu, ir mes dèl to apgailestaujame“, - sakẻ vyriausiasis EK atstovas spaudai R. Kempinen.
} 


\subsection{ES išoriniai ryšiai: prekyba, plètros skatinimas ir humanitarinè pagalba}

Sutarties dèl Europos Konstitucijos projekto 3 straipsnyje ES išorès veiksmu principai ir tikslai apibrèžiami taip: Bendraudama su plačiuoju pasauliu Sajunga išsaugo savo vertybes ir gina savo interesus. Ji padeda išsaugoti taika, užtikrinti sauguma, planetos tvaru vystymasi, tautų tarpusavio solidaruma ir pagarba, laisvą ir sąžininga prekyba, padeda kovoti su skurdu ir apsaugoti žmogaus, ypač vaiko, teises, taip pat griežtai laikosi tarptautinès teisès, isskaitant Jungtiniu Tautu Chartijos principus, ir ja plètoja ${ }^{26}$. Siekiant šių tikslų bei norint kuo labiau padidinti ES įtaką pasaulyje, visiškai suprantama, kad ji turi pasiekti kuo didesnio išorès veiksmų darnumo ir veiksmingumo ne tik ekonomineje, bet ir saugumo bei gynybos užsienio politikoje.

Išorès veiksmams ir BUSP igyvendinti ES šiandien turi savo misijas prie daugelio įtakingiausių tarptautinių organizacijų, per 120 atstovybių trečiosiose šalyse. Šių atstovybių tikslas yra plètoti daugiašalius ir dvišalius ES santykius su tarptautinèmis organizacijomis, ivvairaus dydžio ir turtingumo šalimis bei jų regioninėmis grupėmis. 1997 m. pasirašius Amsterdamo sutartį, Europos Viršūnių Taryba buvo igaliota parengti ilgesnio laikotarpio bendrąsias strategijas, taikomas atskiroms šalims ir regionams $\mathrm{s}^{27}$.

ES šiandien turi nemažai politinių ir ekonominių galių savo įtakai pasaulyje didinti. Tai ir techninio bei ekonominio bendradarbiavimo programos su trečiosiomis šalimis, humanitarinès pagalbos fondai, susitarimai dẻl bendrų diplomatinių veiksmų, priemonés, skirtos konfliktų prevencijai, galimybės sudaryti ịvairių tipų dvišales ir daugiašales sutartis, įvairių veiksmų galimybės tarptautinėse organizacijose ir daugiašaliuose forumuose. Be to, daugelis Sajungos vidaus politikos sričių ir veiksmu gali turèti ịtakos ir projektuojant BUSP globalini lygmeni.

Nors apie 4/5 ES prekybos sudaro tarpusavio vidaus prekyba ir prekyba su Europos kontinento valstybemis, ji tuo pat metu išlieka ir stambiausias prekybos partneris pasaulinëje prekyboje. ES dalis pasaulinëje prekyboje pateikta grafikuose.

1 grafikas: Pasauline prekyba

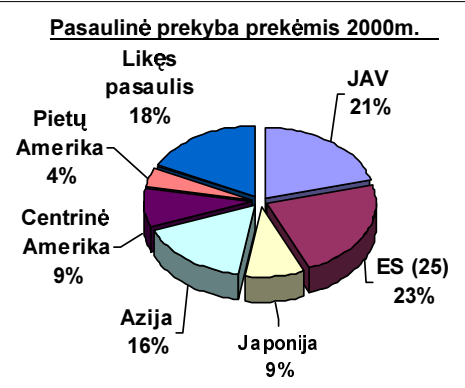

Šaltinis:

http://trade-info.cec.eu.int/doclib/cfm/oclib_section.cfm?sec $=110 \& l e v=2 \&$ order $=$ date

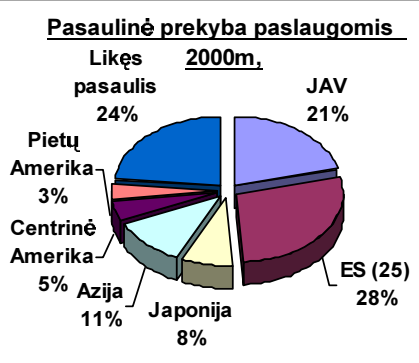

${ }^{26}$ ES konstitucinès sutarties projekto neoficialus vertimas, žr.: http://www.euro.lt/upl_images/ 20030902091859.doc?TopMenuID $=144 \&$ MenuItemID $=382 \&$ ItemID $=3669 \&$ LangID $=1$.

${ }^{27}$ Pvz., Rusijai ir Ukrainai skirtoms bendrosioms strategijoms buvo pritarta 1999 m., o Viduržemio jūros regionui skirta strategija buvo patvirtinta $2000 \mathrm{~m}$. 
Pateikti duomenys rodo, kad ES turi galimybę panaudoti ekonominius ryšius savo politiniams tikslams igyvendinti daugelyje pasaulio regionų ir gana sẻkmingai jais naudojasi.

Vis dèlto ES santykiai su $\mathrm{PPO}^{28}$ ne visada buvo itin sklandūs, nes buvo nesutariama dèl žemès ūkio produktų prekybos. Nesutarimų šiais klausimais kildavo ir tarp pačių ES valstybių. ES pozicijai dèl žemės ūkio produktų prekybos ir šiuo metu daugiausia prieštarauja JAV, Australija, Kanada, daugelis kitų besivystančių valstybių. Nesutarimų tarp ES ir kitų PPO narių kartais kyla ir dėl naujų valstybių, pavyzdžiui, Rusijos prièmimo ị šią organizaciją.

Šiuo metu ES yra didžiausia paramos teikejja pasaulyje ir penktoji pagal dydi negrąžinamų paskolų finansuotoja po JAV, Japonijos, Vokietijos ir Prancūzijos. Nors pati ES teikia tik $10 \%$, tačiau kartu su kitomis ES valstybėmis $-55 \%$ visos pasaulio paramos yra teikiama silpniau išsivysčiusių valstybių plètrai užtikrinti. Kasmetinis ES išorinès paramos portfelis sudaro apie 9,5 milijardo eurų ${ }^{29}$. Savo autoritetą tarptautiniu mastu ES taip pat didina aktyviai dalyvaudama ir finansiškai remdama daugiašales aplinkos apsaugos programas.

Europos Bendrijų vystymosi pradžioje ir vėlesniais metais išorès parama buvo skiriama buvusių ES valstybių narių kolonijoms Afrikoje, Karibų jūros ir Ramiojo vandenyno regionuose, o šiuo metu 2/3 teikiamos paramos tenka Vidurio ir Rytu Europai, buvusioms Sovietų Sajungos respublikoms, Balkanų, Artimujų Rytų, Viduržemio jūros, Azijos ir Lotynų Amerikos regionams. Ši parama teikiama ne tik minètujjų regionų vystymuisi, bet ir institucijų stiprinimui skatinti, makroekonominèms programoms ir žmogaus teisèms užtikrinti.

Kalbant apie atskirus pasaulio regionus, pirmiausia reikia pabrèžti ES santykius su Šiaurès Amerika. JAV yra didžiausia ES partnerè, su kuria ji ypač artimai bendradarbiauja daugelyje sričių, pradedant prekyba bei politika ir baigiant užsienio politika bei saugumu. Dabartiniai ES - JAV santykiai grindžiami šiais dokumentais: 1990 m. Transatlantine deklaracija, kurioje numatoma dvišalius viršūnių susitikimus rengti du kartus per metus; 1995 m. Naujaja transatlantine darbotvarke, kurioje, be kitų klausimų, įsipareigojama prisidèti prie pasaulinès prekybos plètros ir tarpusavio ryšių stiprinimo; 1998 m. pasirašytu transatlantinès ekonominės partnerystės dokumentu, ipareigojančiu šalinti technines dvišalès prekybos kliūtis ir skatinti daugiašali liberalizavimą, $1999 \mathrm{~m}$. Bonos deklaracija ${ }^{30}$, kurioje kalbama apie visapusę ir lygiavertę ekonomikos, politikos ir saugumo sričių partnerystę.

ES ir JAV šiuo metu yra du pagrindiniai pasaulinès ekonomikos veikejjai. Kartu paemus jiems tenka beveik puse pasaulio ekonomikos ir prekybos srautų, o jų investicijos sudaro beveik 1 milijardą eurų per dieną. Jos yra viena kitos vienintelis didžiausias partneris bei svarbiausias užsienio investicijų šaltinis ir investavimo vieta. Jų svarbą viena kitai iliustruoja ES paslaugu prekybos grafikas: JAV tenka beveik 2/3 ES paslaugų prekybos. Aktyviai tarpusavio ryšius padeda plètoti ir JAV bei ES verslo bendruomenès, palaikančios abipusį transatlantinio verslo dialogą. $2000 \mathrm{~m}$. prekybos ir investicijų apimtis tarp JAV ir ES buvo daugiau nei vienas trilijonas ${ }^{31}$ eurų.

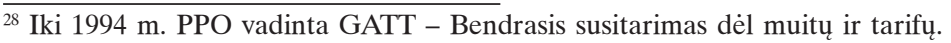

${ }^{29}$ Europos komisijos delegacijos Lietuvos informacija, žr.: http://www.eudel.lt/lt/es_pasaulyje/isipareigojimai.htm.

${ }^{30}$ Bonos deklaracija, pasirašyta 199906 21, http://www.projecteu.com/usa.htm.

${ }^{31}$ Vien $2002 \mathrm{~m}$. ES importavo iš JAV prekių už $174 \mathrm{mlrd}$. eurų ir paslaugų už $120 \mathrm{mlrd}$. eurų. ES prekių eksportas ị JAV sudarẻ 238 mlrd. eurų, o paslaugų - 116 mlrd. eurų, žr.: http://europa.eu.int/ comm/trade/issues/bilateral/countries/usa/index_en.htm. 
2 grafikas: ES paslaugų prekybos $2002 \mathrm{~m}$. struktūra

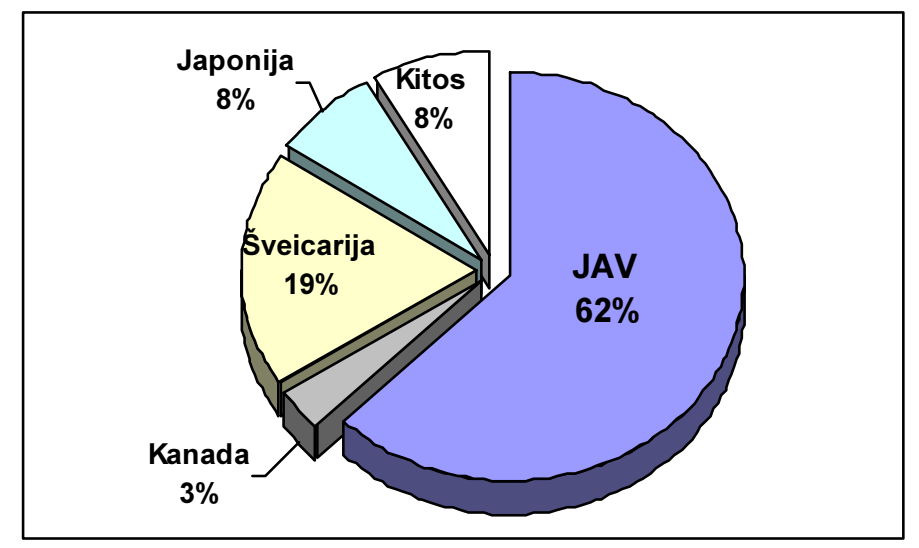

Šaltinis: EUROSTAT

Vis dèlto platus ES ir JAV ekonominis bendradarbiavimas neapsaugo transatlantinio ryšio nuo daugybès nesutarimų įvairiose srityse: Europos šalys kritikuoja JAV dèl Kioto protokolo neratifikavimo, mirties bausmés taikymo, plieno importo muitų, neprisijungimo prie Tarptautinio baudžiamojo tribunolo; JAV savo ruožtu netenkina ES žemės ūkio politika, genetiškai modifikuotų produktų importo embargas, per mažas karinis įnašas ị NATO. Galiausiai Irako krize išryškino kai kuriuos esminius nesutarimus dẻl pačios tarptautinès saugumo sistemos prigimties.

Vienas iš strateginių ES prioritetų yra taikos ir stabilumo grąžinimas į Balkanų regioną Pietryčių Europoje bei šio regiono šalių įtraukimas į Europos politinị ir ekonominį gyvenimą. 1999 m. Kelne vykusiame ES viršūnių susitikime valstybių ir vyriausybių vadovai prièmė Pietryčiu Europos stabilumo paktą ${ }^{32}$. Šiame dokumente didžiausias dėmesys skiriamas regioninio bendradarbiavimo iniciatyvoms verslo ir aplinkos apsaugos srityse, kovai su korupcija bei organizuotu nusikalstamumu. Stabilizavimo ir būrimo ị bendras struktūras procesas yra pagrindinè politikos priemonè, kurią ES taiko Albanijai, Bosnijai ir Hercegovinai, Kroatijai, Serbijai ir Juodkalnijai bei Makedonijai. Vykstantis procesas apima ekonominę ir finansinę pagalbą, bendradarbiavimą, politinį dialogą, tikslą tapti laisvosios prekybos zona, ES teisès aktų ir praktikos derinimą. Minètoms Pietryčiu Europos šalims ES teikia svarią finansinę ir techninę pagalbą. Paskutiniame praejusio amžiaus dešimtmetyje ES šiam regionui skyrè 4,5 milijardo eurų, o 2000-2006 m. finansinè ir techninè pagalba regionui bus dar didesne $\dot{e}^{33}$.

\footnotetext{
32 Pati dokumentą galima rasti: http://www.stabilitypact.org/stabilitypactcgi/catalog/ cat_descr.cgi?prod_id $=1806$.

${ }^{33}$ Europos komisijos delegacijos Lietuvos informacija, žr.: http://www.eudel.lt/lt/es_pasaulyje/isipareigojimai.htm.
} 
Gana glaudžius ir visapusiškus ryšius ES palaiko su Viduržemio jūros regiono valstybėmis. $1995 \mathrm{~m}$. pab. 15 ES valstybių ir 12 Viduržemio jūros šalių prièmé Barselonos deklaraciją ${ }^{34}$. Siekdama iggyvendinti Deklaracijoje užsibrèžtus uždavinius, ES jau yra pasirašiusi dvišalès asociacijos sutartis su Maroku, Tunisu, Jordanija, Palestinos savivalda ir Izraeliu. Šio proceso tikslas - iki 2010 m. sukurti Europos ir Viduržemio jūros regionų laisvają prekybos zoną. Siekdamas padèti Viduržemio jūros regiono partneriams ịveikti su laisvaja prekyba susijusius sunkumus, Europos investicijų bankas kasmet šiam regionui skiria vieną milijardą eurų negrą̌̌intinų ir vieną milijardą eurų grą̌intinų paskolų. Šiuo metu jau vyksta gana platūs prekybiniai mainai tarp ES ir šio regiono valstybių. Ekonominio bendradarbiavimo apimtis 2000 m. siekè 2,2 milijardo eurų ${ }^{35}$.

Jau ne pirmą dešimtmeti (tačiau ne itin sèkmingai) ES dalyvauja ir Artimujụ Rytų taikos procese. ES laikosi principo, kad šio regiono šalių bendradarbiavimas ir ekonominè pažanga įgalintų pasiekti ilgalaikị susitarimą. Tai, be abejonès, reikalauja ir didelès finansinès paramos. ES yra prisièmusi atsakomybę pirmininkauti Regiono ekonominès plètros darbo grupei. ES yra didžiausia donorè Palestinoje, kuriai 19941999 m. ji skyrė 1,6 milijardo eurų - tai sudarė $60 \%$ visos tarptautinès paramos ${ }^{36}$. 2003 m. ES kartu su kitomis ketverto naremis - Rusija, JAV ir JT - pagaliau pavyko priimti ilgai lauktą taikos planą (ang. Roadmap), tačiau nesiliaujantis abipusis kraujo praliejimas ir toliau griauna visas taikos viltis.

ES ekonominiai santykiai su Rusija ir Nepriklausomų valstybių sandraugos (NVS) šalimis yra vystomi remiantis TACIS programa. Šia programa siekiama perteikti patirtí, skatinančią pereiti prie rinkos ekonomikos, stiprinti demokratiją ir kurti teisinę valstybę. Šiuo metu vykdomoje septynerių metų programoje daugiausia dèmesio skiriama viešojo administravimo reformai, privataus sektoriaus plètrai ir galimoms perëjimo prie rinkos ekonomikos socialinėms pasekmėms. Gana didelę reikšmę ES išoriniams santykiams turi ekonominiai ryšiai su Rusija. Ypatingas dèmesys skiriamas energetinių žaliavų, pirmiausia dujų, importui iš Rusijos ir NVS šalių. $2001 \mathrm{~m}$. ES prekybos apimtis su Rusija sudaro 65 milijardus eurų ${ }^{37}$.

ES ekonominiai ryšiai pletojami ir su Azijos regiono (Japonija, Kinija, Pietu Korejja, Malaizija, Singapūras ir kt.), Afrikos bei Lotynų Amerikos valstybèmis.

\subsection{ES ekonominiai ryšiai su Lietuva}

Būtų naivu manyti, kad Lietuva yra ypač svarbi ES prekybos ir investicijų partnerè, tačiau, kalbant apie Lietuvos ekonominių ryšių plètrą su ES šalimis, galima pastebėti, kad jie per pastaruosius metus nuolat didejo ir šiuo metu sudaro apie pusę (48\%) Lietuvos užsienio prekybos apimties (prekybos dinamiką atspindi grafikas). Stambiausi Lietuvos prekybos partneriai $2002 \mathrm{~m}$. buvo D. Britanija (2,73 milijardo Lt), Vokietija (2,10 milijardo Lt), Danija (1,04 milijardo Lt), Švedija (0,85 milijardo

${ }^{34}$ http://euromedrights.net/english/barcelona-process/barcelona_declaration.htm.

${ }^{35}$ European Commission Annual report on MEDA program 2000, p. 4., http://europa.eu.int/ comm/europeaid/reports/meda_2000_en.pdf.

${ }^{36}$ Ten pat.

37 Žr.: http://europa.eu.int/comm/external_relations/russia/intro/trade.htm. 
Lt), Prancūzija (0,83 milijardo Lt), Olandija (0,64 milijardo Lt), Italija (0,57 milijardo Lt). Šie duomenys rodo, kad Lietuva šiuo metu palaiko plačius ir gana reikšmingus ekonominius ryšius su visomis pagrindinėmis ES valstybėmis. Vidurio ir Rytų Europos valstybėms (CEFTA) tenka 7,3\% Lietuvos užsienio prekybos, EFTA narèms dar apie 3,4\% (žr. 3 grafiką). İdomu pastebėti, jog praejjusio dešimtmečio vidurio prekybos ryšiai su NVS šalimis nuolat mažèjo: 1996 m. NVS šalims teko 38 \% Lietuvos užsienio prekybos, o $2002 \mathrm{~m}$. jau tik $23 \%$.

3 grafikas: Lietuvos užsienio prekybos dinamika 1996 - 2002 m.

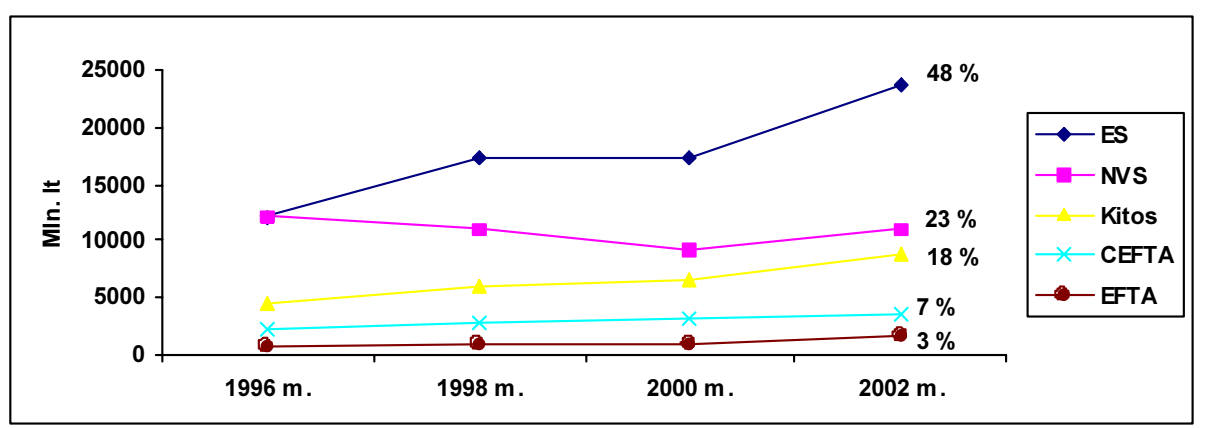

Šaltinis: LR Statistikos departamentas, 2003 m.

Tiesioginès užsienio investicijos Lietuvoje iš ES šalių šiuo metu siekia 7840 milijonų litų, arba $60 \%$ visų investicijų (žr. 4 grafiką). İdomu pastebèti, jog per pastaruosius trejus metus pastebimai išaugo ir NVS, ypač Rusijos, verslininkų aktyvumas Lietuvoje: investicijos išaugo nuo 153 milijonų Lt 2000 m. iki 702 milijonų Lt 2003 m. Taip pat reikia pastebėti, jog šie skaičiai dar neatspindi dabar vykstančios valstybinių Lietuvos įmonių privatizacijos, kurioje Rusijos kapitalas reiškiasi itin aktyviai.

4 grafikas: Tiesioginès užsienio investicijos Lietuvoje 2003 m.

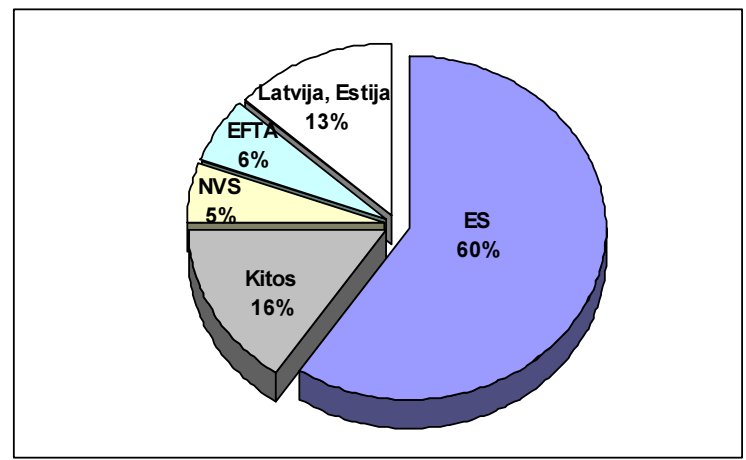

Šaltinis: LR Statistikos departamentas, 2003 m. 
Pateikta ES ekonomikos išorès santykių su pasauliu ir Lietuva apžvalga leidžia teigti, kad šiuo metu ES yra viena iš stipriausių veikèjų pasaulio ekonomikoje. Didžiulis ekonominis potencialas, platūs ir visapusiški tarptautiniai ryšiai visuose pasaulio regionuose, parama silpniau išsivysčiusioms valstybèms, humanitarinè pagalba stichinių nelaimių bei karinių konfliktų atvejais turètų suteikti Europos Sajungai svarų žodị užtikrinant taiką ir stabilumą ne tik Europoje, bet ir pasaulyje. Vis dèlto ES ekonominiai pasiekimai netapo BUSP sékmės garantija -ES saugumo politika patyrẻ nemažai nesẻkmių ir krizių, kurios iki šiol gerokai apsunkino ES galimybes tapti ir svarbiu tarptautinès saugumo sistemos veikèju. Persiliejimo (ang. spill-over) efektas sėkmingai veikè ekonomikos srityje, tačiau taip pat natūraliai neveikia BUSP srityje. Tai galima aiškinti skirtinga rinkos ekonomikos, kurios varomoji jèga yra naudos siekimas, ir užsienio politikos, kuri remiasi (ar bent turètų remtis) nacionaliniais interesais, prigimtimi. Vis dẻlto pastaraisiais metais ES pasiekè ir tam tikrą gynybos integracijos pažangą. Šie procesai atsispindi ir kintančioje Lietuvos politikoje BUSP atžvilgiu.

\section{Lietuvos santykio su BUSP evoliucija: galimybès ir iššūkiai}

G. Vitkaus teigimu, dar prieš prasidedant stojimo į ES deryboms (2000 m. vasaris), Lietuva jau buvo aktyvi daugiašalio politinio dialogo su ES BUSP srityje dalyvie ${ }^{38}$. Lietuva reguliariai prisijungdavo ir paremdavo ES pozicijas ir deklaracijas. Iki $2001 \mathrm{~m}$. Lietuva buvo prisijungusi prie $611 \mathrm{ES}$ pareiškimų, demaršų ir bendrų pozicijų, tarp jų ir JT bei ESBO organizacijose. Tik 10 kartų Lietuva nusprende to nedaryti ir dauguma atvejų buvo susiję su ESBO misijomis Latvijoje bei Estijoje ir jų rusakalbių mažumų klausimu. Dar daugiau - Lietuva uždare BUSP derybų skyrių vos joms prasidejus $-2000 \mathrm{~m}$. gegužès $25 \mathrm{~d}$. Lietuva nepraše jokio pereinamojo laikotarpio šioje srityje ir visiškai atitiko visus teisinius acquis reikalavimus BUSP srityje. $2001 \mathrm{~m}$. Lietuva prisijungè prie 605 ES pozicijų, 2002 $\mathrm{m}$. prie 471 pozicijos, o per pirmus keturis $2003 \mathrm{~m}$. ménesius prie $80 \mathrm{ES}$ poziciju $\mathrm{u}^{39}$.

ES plètros įtaka Lietuvos vidaus ir užsienio politikai nekelia abejonių. Kaip teigia K. Maniokas, naujausios studijos ES tematika autorius, „ES poveikis valstybėms kandidatėms yra itin didelis tiek intensyvumu, tiek apimtimi“ ${ }^{“ 40}$. K. Maniokas nuodugniai aptare Europos integracijos ir su ja susijusio prisitaikymo, vadinamosios europeizacijos, padarinius Lietuvai kitų VRE valstybių kontekste. İvertinęs Kopenhagos kriterijų igyvendinimo Lietuvoje poveikį ${ }^{41}$, autorius padare išvadą, jog „ES plètra iš esmès prisidejo prie demokratijos konsolidavimo, regioninio ir vidaus politinio stabilumo, ekonominio augimo ir valstybės institutų plètros"42 . Reikia pastebèti, jog visi šie padariniai yra labiau susiję su Lietuvos vidaus politika (tiek, kiek ją galima atskirti nuo užsienio ir saugumo politikos,_turint omeny europeizacijos ir globalizacijos kontekstus).

\footnotetext{
${ }^{38}$ Missiroli A. , eds., „Bigger EU, wider CFSP, stronger ESDP?“, Occasional Paper, No. 34, April 2002, p. 14.

${ }^{39}$ LR Užsienio reikalų ministerijos Europos integracijos departamento informacija.

${ }^{40}$ Maniokas K., (note 1), p. 132.

${ }^{41}$ Kopenhagos kriterijai paskelbti 1993 m. ES viršūnių tarybos susitikime Kopenhagoje: politinis arba demokratijos kriterijus, ekonominis arba laisvosios rinkos kriterijus ir pilnas acquis peremimas.

${ }^{42}$ Maniokas K., (note 1) p. 182.
} 
Nepaisant tokios akivaizdžios ir empiriškai pagrindžiamos pozityvios eurointegracijos įtakos Lietuvai, šio straipsnio autoriai mano, jog Lietuvos santykis su antruoju ramsčiu - BUSP yra kontroversiškesnis negu indikuotų greitai ir lengvai uždarytas derybų skyrius dèl BUSP. Atrodytų sẻkmingi oficialių derybų su ES rezultatai atspindi tik formaliają Lietuvos santykio su ES BUSP pusę. Nèra taip sunku apsispręsti paremti ES poziciją, jeigu yra smerkiami žmogaus teisių pažeidimai ar genocidas kokioje nors autoritarinèje valstybėje. Vis dèlto Irako krizè parodè, jog Lietuvai gali kilti kur kas didesnių dilemų, kai sprendžiami svarbiausi tarptautinio saugumo klausimai. Priimti sprendimą Irako nuginklavimo klausimu buvo palyginti paprasta, nes pati ES neturëjo vieningos nuomonès. Ateityje tokios dilemos gali labai paaštrèti, jeigu buvęs antrasis ramstis, kaip tai numato ES Konstitucijos projektas, pasislinks arčiau pirmojo ir ịgis daugiau viršvalstybinių bruožų bei funkcijų ${ }^{43}$.

Sis klausimas yra labiausiai susijęs su minèta Lietuvos saugumo identiteto dualumo problema. Praẻjusio dešimtmečio pradžioje prasidejjus euroatlantinès integracijos procesams tarp Lietuvos politinio elito išsikristalizavo tokia neoficiali integracijos formulè: narystė NATO turètų garantuoti Lietuvai ilgalaikị saugumą pačia „kiečiausia“ -5 straipsnio, t. y. kolektyvinès gynybos - prasme. Tuo pat metu narystė ES turètų garantuoti šaliai ekonominę gerovę ir socialinį stabilumą - vadinamaji minkštaji saugumą. Kai kurie lietuvių autoriai netgi teigia, jog „de facto narystė NATO gan ilgą laiką - bent jau iki 1999 metų - buvo Lietuvos užsienio politikos prioritetas Nr.1" ${ }^{\prime 4}$. Šio straipsnio autoriai tokị teigini yra linkę laikyti esant pernelyg drąsų ir manytų, jog abu procesus vis dèlto reiktų vertinti kaip daugiau ar mažiau lygiavertès, nors savo turiniu skirtingos, reikšmès Lietuvai. Tai, kad iki 1999 m. derybų dẻl narystès su ES (beje, kaip ir NATO Narystės veiksmų plano) pradžios Lietuvos politinis elitas iš tiesų daugiau pastangų rodè integracijai į NATO, sąlygojo daugiau ar mažiau objektyvi priežastis: pamažu blèstanti, bet vis dar gaji Rusijos baimè ir netikrumas dèl ilgalaikių saugumo garantijų. Oficialiuose Lietuvos diplomatų ir politikų pasisakymuose narystės Euroatlantinèse institucijose formulè skamba gana aptakiai: „Narystė ES nepakeičia narystės NATO, bet papildo viena kitą“. Vis dèlto vargu ar kas nors ryžtųsi neigti, jog narystės ES pasekmės valstybių nariu vidaus ir užsienio politikai bei tarptautiniam statusui yra kur kas fundamentalesnès negu narystės NATO pasekmès. Nereikètu apsigauti kalbant apie vienos ar kitos organizacijos prioritetizavimą vienu ar kitu laikotarpiu. Galima daryti prielaidą, jog kitos šalys, siekiančios narystės abiejose organizacijose, vadovaujasi panašiais išskaičiavimais, nors kai kuriais atvejais galima pastebèti ir tam tikras preferencijas narystès vienoje ar kitoje organizacijoje atžvilgiu. Net ir daugelyje senujų ES narių Šaltojo karo metais vyravo tokios pat nuostatos: NATO buvo suprantama kaip saugumo garantas, o ES - kaip gerovès tiekejja. Vis dèlto Šaltojo karo pabaiga, ES BUSP, o vẻliau ir ESGP iniciatyvos įnešè tam tikrų pokyčių i i šią lygtị.

\footnotetext{
${ }^{43}$ ES Konstitucijos projekte yra atsisakyta ES skirstymo ị tris „ramsčius“.

${ }^{44}$ Nekrašas E., (note 23) p. 17.
} 


\subsection{ESGP ir jos pasekmès Lietuvai}

Po 1980-ujjų eurosklerotinès stagnacijos dešimtojo dešimtmečio pradžia suteikè ypač daug vilčių: išnykusi Sovietų Sajungos grẻsmė, atsivèrusios Rytų Europos sienos, Vokietijos unifikacija, bręstanti krize Balkanuose - ES tapo savotiška stabilumo sala permainų vandenyne. ES, kaip civilinès galios, statusas, turtingų liberalių valstybių klubas, atrodè itin gerai pasiruošęs imtis lyderio vaidmens naujoje aplinkoje, kurioje karinès galios reikšmè lyg ir tapo mažesnè ir net imta kalbėti apie NATO paleidimą. Netgi JAV parèmé didesnị ES vaidmenį sprendžiant jos pačios saugumo klausimus. Vis dèlto euforija greitai ištirpo: atotrūkis tarp ES norų tapti svarbiu tarptautiniu saugumo sistemos veikeju ir galimybiu ịgyvendinti siekius išryškejjo iš karto po Maastrichto sutarties, kadangi pasirodé, jog Europa yra visiškai nepajègi viena tvarkytis su vidaus krizèmis,- tai ịrodè Balkanų situacija. Juk tik NATO déka 1995 m. buvo pasirašyta Deitono taika. ES jau seniai ir bergždžiai stengiasi sureguliuoti Artimujų rytų taikos procesą. Net ES plètros procesą į rytus skatino prasidejjusi NATO plètra. Kosovo krizės metu išryškejjo ir beviltiškas karinis ES atsilikimas nuo JAV. Visa tai sąlygojo ị 1998 m. prasidejusį ESGP - Europos saugumo ir gynybos politikos kūrimo procesą.

1998 m. St. Malo mieste (Prancūzija) susitikę Didžiosios Britanijos Ministras Pirmininkas T. Blair ir Prancūzijos Prezidentas J. Chirac pasirašẻ deklaraciją, ǐšreiškusią įsitikinimą, jog „Europos Sajunga privalo turèti veiksmu autonomija, paremta patikimomis karinemis pajegomis, gebančiomis reaguoti i tarptautines krizes ${ }^{645}$. Sis dvieju Europos šalių pareiškimas buvo svarbus impulsas ES Viršūnių tarybos priimtiems sprendimams Kelne (1999 06) ir Helsinkyje (1999 12) kurti bendrają ESGP. Iki St. Malo Europos gynybos politika rèmėsi keliais neginčytinais principais: 1) Europos saugumo ir gynybos identitetas galèjo būti plètojamas tik NATO kontekste ir tik su JAV pritarimu; 2) Vakarų Europos Sajunga (VES) turëjo būti organizacinė Europos gynybinio bendradarbiavimo struktūra, glaudžiai susieta su NATO; 3) ES ir jos BUSP faktiškai nebuvo numatytas joks realus vaidmuo Europos gynyboje. Dvišalẻ britų ir prancūzų St. Malo deklaracija paskelbè apie būtinybę suteikti ES autonomišką gynybos dimensiją. Neatsitiktinai būtent Didžioji Britanija ir Prancūzija inicijavo ESGP: tik šios dvi šalys turi tam tikrą ateities strategiją, kuri ne tik projektuojama už Europos ribų, bet ir turi pakankamai karinių, politinių bei ekonominių išteklių savo interesams paremti ir apsaugoti. Abi šalys turi branduolinị ginklą ir abi yra nuolatinès Jungtinių Tautų Saugumo tarybos narès. Todèl bet kokie savarankiški Europos gynybos planai be Prancūzijos ir Didžiosios Britanijos karinių pajègų ir resursų būtų beviltiški. Iki šiol būtent Didžioji Britanija buvo didžiausia euroskeptikè ir priešinosi visiems bendros gynybos planams, kurie galètų pakenkti specialiajam ryšiui su Vašingtonu. Kita vertus, Prancūzija iki šiol buvo didžiausia Europos autonomijos nuo JAV šalininkè, taigi negalejo nepriimti šios Blair pasiūlytos iniciatyvos kurti bendrą saugumo ir gynybos politiką.

${ }_{45}$ Žr.: Joint declaration issued at the British-French Summit, St-Malo, France, 3-4 December 1998 / Howorth J. European Integration and defence: the ultimate challenge? Chaillot Papers 43, 2000. 
Netiesiogiai ESGP atsiradimą galima sieti ir su bendros valiutos - euro įvedimu ES nuo 1999 m. pradžios, žymèjusiu precedento neturintị valstybių ekonominès integracijos apogejųc. Tapo aišku, jog bendriems ES interesams ginti reikalinga bendra užsienio politika, paremta adekvačiais instituciniais, politiniais ir kariniais pajègumais, o ne abstrakčiomis ir faktiškai nesaistančiomis bendrosiomis pozicijomis. Bendra užsienio politika sunkiai įsivaizduojama be saugumo politikos, kuri savo ruožtu nebus patikima be tam tikros bendros gynybos dimensijos. Pagaliau Kosovo karas, atskleidęs Europos priklausomybę nuo JAV technologijų ir resursų, palengvino politinị ir teisinị ESGP ịtvirtinimą ES Viršūnių tarybos susitikimuose Kelne ir Helsinkyje. ESGP iniciatyva remiasi dviem pagrindinemis tarpusavy susijusiomis prielaidomis: JAV negalès arba nenorès įsitraukti ị kiekvieną Europoje ar jos periferijoje kylančią krizę, todèl jeigu Europos valstybėms nepavyks modernizuoti savo ginkluotujų pajëgų bei sukurti adekvačių krizių valdymo pajẻgumų, Europa liks pažeidžiama ir nepajègi spręsti savo saugumo problemų. Kaip yra pažymėjęs NATO generalinis sekretorius George L. Robertson, šiuolaikinèje saugumo aplinkoje turèti tik du pasirinkimus - NATO arba nieko - būtų pražūtinga Europai.

Kelno ES Viršūnių taryba nustate institucinę ESGP struktūrą, kuri daugeliu atžvilgių yra analogiška NATO politinei ir karinei sąrangai. Buvo sukurtos naujos politinio ir strateginio vadovavimo institucijos: buvęs NATO generalinis sekretorius J. Solana buvo paskirtas pirmuoju ES Aukštuoju igaliotiniu bendrajai užsienio ir saugumo politikai, sukurtas Politikos ir saugumo komitetas (PSK), Europos karinis komitetas (EKK) - aukščiausia ES karinè institucija ir Europos karinis štabas (EKŠ), kurio paskirtis - užtikrinti karinę ekspertizę ES vadovaujamoms operacijoms. Šios reformos tapo savotišku vieno Europos balso idèjos įkūnijimu ir atsakymu ị JAV Prezidento R. Nixon patarẻjo H. Kissinger klausimą: „I ką mums Europoje kreiptis?“. Atsakomybès už BUSP akumuliacija viename asmenyje taip pat išreiškė ES politinę valią kurti vieningą politinio karinio planavimo, analizės ir politikos konsultavimo centrą. Vis dèlto naujų institucijų sukūrimas savaime negarantavo efektyvaus sprendimų prièmimo ar juo labiau efektyvaus jų igyvendinimo. Kad ESGP taptų veiksminga, buvo būtina sukurti ne tik ir ne tiek naujas sprendimų prièmimo institucijas, kiek efektyvias karines pajègas.

ES Helsinkio Viršūnių susitikimo metu ES šalių vadovai paskelbẻ pagrindini ESGP tikslą (ang. Headline Goal): sukurti 60000 karių greitojo reagavimo pajègas Petersbergo uždaviniams (humanitarinėms, taikos palaikymo bei krizių valdymo operacijoms) vykdyti, kurias per 60 dienų būtų galima išsiųsti i krizès vietą ir išlaikyti mažiausiai metus. Europiečiams paskelbus šį ambicingą planą, saugumo politikos ekspertai iškẻlè tris esminius klausimus: kam reikalingos naujos pajègos, kaip jos paveiks JAV ir Europos/NATO ir ES santykius ir pagaliau ar europiečiai yra pasirengę išleisti pakankamai pinigų.

Atsakydami i pirmą klausimą, europiečiai paprastai kartoja Helsinkio nutarimuose užfiksuotą argumentą: naujų pajëgų misija bus veikli ten, kur NATO kaip visuma nedalyvaus. Kitas klausimas, kur tai galètų būti-Europoje ar kur kitur. ES nutarimai nenustatè geografinių ribų, kuriose ES ịsipareigoja imtis krizių valdymo operacijų, tačiau galima spèti, jog prerogatyva būtų teikiama krizėms, kylančioms Europos erdvejje ir ypač jos neintegruotoje periferijoje. ES 2003 m. èmèsi taikos 
palaikymo misijos Makedonijoje, siekia perimti SFOR misiją Bosnijoje ir Hercegovinoje iš NATO ir svarsto galimybę pradèti misiją Moldovoje. Vis dèlto J. Solana vienoje kalboje yra pažymėjęs, jog „,krizé gali kilti bet kuriame pasaulio taške, o tai kelia didelius reikalavimus mūsu pajegoms" . Kitaip tariant, ES, siekdama įgyti didesnị vaidmeni pasaulyje, turi gebėti reaguoti globaliai. Pirmaja tokia ES misija tapo 2003 m. vasarą Kongo Demokratineje Respublikoje pradèta operacija „Artemis“.

Kitas klausimas, ar europiečiai pasiruošę atitinkamai mokèti už naujas pajėgas. Iš pirmo žvilgsnio, pagrindinis Helsinkyje iškeltas tikslas neatrodo toks ambicingas, turint omeny tai, kad ES narių kariuomenèse tarnauja 1,8 milijono karių (JAV -1,3 milijono), o gynybai ES šalys išleidžia penktadali viso pasaulio karinių išlaidų per metus. Vis dèlto galima abejoti europiečių pasiryžimu investuoti ị krizių valdymą ir savo pačių saugumą apskritai: nuo Šaltojo karo pabaigos daugelio šalių karinès išlaidos nuolat mažejo ir tik pastaruoju metu stabilizavosi. Prancūzija gynybos reikmėms 2001 m. išleido 2,6\%, Didžioji Britanija 2,4\%, Vokietija 1,5\% savo šalių BVP (plg. JAV išleido 3,2\% BVP). $2002 \mathrm{~m}$. JAV išleido 343 milijardus USD, o $2003 \mathrm{~m}$. išleis jau beveik 400 milijardus USD, arba 3,5\% BVP, t. y. apie pusę viso pasaulio kariniu išlaidų. Optimizmą kelia nebent tai, jog daugelio ES šalių gyventojai remia savarankišską Europos saugumo ir gynybos politiką. Pavyzdžiui, net 79\% Vokietijos ir Prancūzijos gyventojų pasisako už bendrą ESGP, o ES vidurkis - 73\%. Klausimas, ar jie pasirengę atitinkamai mokèti už savarankišką saugumo ir gynybos politiką, lieka retorinis.

Ekspertų vertinimu, Helsinkio tikslui igyvendinti, t. y. 12 mėnesių trunkančios operacijos pajėgų rotacijai užtikrinti, yra reikalingi tokie pajègumai ${ }^{46}: 200000$ 230000 sausumos pajègų karių, 300-350 kovinių orlaivių, 180 paramos lèktuvų, 3-4 vykdomosios grupés po 20 fregatų. $2000 \mathrm{~m}$. i̇vykusioje pajëgumų planavimo konferencijoje ES valstybės ir šalys partnerès nurode 100000 karių, 400 orlaivių ir 100 laivų įnašą i greitojo reagavimo pajėgas. Tokio ịnašo lyg ir turètų pakakti jūrų ir oro pajègu elementams, o Europos šalių gausios kariuomenès leidžia manyti, jog ir sausumos pajëgų personalo komplektavimo klausimas neturètų kelti didelių sunkumų. Egzistuoja kita problema - realūs, o ne popieriniai koviniai pajègumai. Tam tikru atžvilgiu ES šalių kariuomenių dydis ir yra tų pačių kariuomenių ginkluotès bei ịrangos modernizacijos stabdys, be kurių Europos kariškiai negalès vykdyti šiuolaikinių operacijų. Atrodo, jog ES ir po $2003 \mathrm{~m}$. dar nebus pajègi viena imtis tokių sudètingu kovinių operacijų, kaip NATO karinè kampanija Kosove ar Irako laisvè.

Pajëgumų stiprinimo konferencijoje Briuselyje $2001 \mathrm{~m}$. ES narès ir šalys partnerès nurodè papildomą įnašą i greitojo reagavimo pajëgas, kuris turètų užglaistyti kai kurias pajègumų spragas ${ }^{47}$. ES pareigūnai atkreipè dėmesį, jog ES bus pajègi vykdyti operacijas tose srityse, kur NATO iki šiol nebuvo labai aktyvi, visų pirma civilinès policijos operacijas. $2002 \mathrm{~m}$. pradžioje ES valstybių užsienio reikalų ministrai prièmè sprendimą dislokuoti 500 policijos pareigūnų kontingentą Bosnijoje, perimant iki šiol Jungtinių Tautų vykdytą operaciją. Tai tapo pirmaja ES civiline operacija, tiesiogiai susijusia su ESGP.

${ }^{46} \check{Z}$ r.: Howorth J., „European integration and defence: the ultimate challenge?“, Institute for Security Studies of WEU: Chaillot Paper 43, 2000, p. 39-40.

${ }^{47}$ Detalius šalių nurodytus įnašus į ES greitojo reagavimo pajëgas žr.: Paulauskas K., „Europos gynybos politika po St. Malo deklaracijos “, Krašto apsauga, 4 (7), 2002, p. 7-11. 
Kaip ir reiktų tikètis, liūto dalị naštos formuojant bendras ES pajègas yra prisiėmusios Prancūzija, Didžioji Britanija ir Vokietija. Lietuva taip pat yra nurodžiusi gana apčiuopiamą įnašą į ES pajėgas ${ }^{48}$, netgi vieną didžiausių tarp būsimų ES narių. Reikia turèti omeny, kad panašų pajègų krepšelį Lietuva nurodys ir NATO operacijoms. Lietuva vadovaujasi principu, jog, turédama vieną kariuomenę, turi tik vienus karinius standartus - NATO standartus (ES kol kas nèra sukūrusi savo vieningų standartų, nors ir nèra pareiškusi, kad ruošiasi laikytis NATO standartų formuodama savo pajègas). Dèl finansinių ir kitų materialinių apribojimų Lietuva negali turèti atskirų pajėgų ES ir atskirų NATO operacijoms vykdyti, nors anksčiau ar vėliau gali susiklostyti tokia situacija, kurioje tiek NATO, tiek ES prašys Lietuvos įnašo i jų operacijas, o Lietuva galés prisidèti tik prie vienos.

Iki šiol realus Lietuvos ịnašas į ES vadovaujamas operacijas buvo minimalus (žr. 1 lentelę). İdomu pastebèti, jog šiuo metu didžiausia dalis 2003 m. Lietuvos užsienyje dislokuotų karių teko net ne NATO operacijoms, bet ad hoc koalicijai Irake ir JAV operacijai Enduring Freedom Afganistane - iš viso 147 kariai. NATO vadovaujamose operacijose $2003 \mathrm{~m}$. antroje pusēje dalyvavo daugiau nei 130 karių.

1 lentelè: Lietuvos dalyvavimas tarptautinèse operacijose 2003 m.

\begin{tabular}{|c|c|}
\hline OPERACIJOS & LIETUVOS INAŠAS IR ŠALIS PARTNERE் \\
\hline \multicolumn{2}{|l|}{ NATO OPERACIJOS } \\
\hline KFOR, Kosovas & $\begin{array}{l}100 \text { karių BALTSQN-8 misija su Danijos pajègomis } \\
30 \text { kariu KFOR-8 misija su Lenkijos pajègomis. }\end{array}$ \\
\hline SFOR, Bosnija ir Hercegovina & 1 karininkas Joint Forge operacijoje su JAV pajėgomis \\
\hline ISAF, Afganistanas & 2 karo medikai su Vokietijos karo ligonine. \\
\hline \multicolumn{2}{|l|}{ ES OPERACIJOS } \\
\hline Operacija Concordia, Makedonija & 1 karininkas ES misijoje. \\
\hline $\begin{array}{|lrr|}\text { Operacija } & \text { Artemis, } & \text { Kongo } \\
\text { Demokratine } & \text { Respublika } & \\
\end{array}$ & \\
\hline \begin{tabular}{|lll}
$\begin{array}{l}\text { Policijos misija, } \\
\text { Hercegovina }\end{array}$ & Bosnija ir \\
\end{tabular} & \\
\hline \multicolumn{2}{|l|}{ KITOS OPERACIJOS } \\
\hline Irako laisvè, Irakas & $\begin{array}{l}54 \text { kariai Danijos kontingente. } \\
45 \text { kariai Lenkijos sektoriuje. } \\
8 \text { logistai su amerikiečiais. }\end{array}$ \\
\hline Tvari taika, Afganistanas & 40 spec. pajėgų karių su amerikiečiais. \\
\hline
\end{tabular}

Šaltinis: LR Krašto apsaugos ministerijos duomenys.

\subsection{ESGP perspektyvos ir transatlantiniai santykiai}

Vis dèlto ESGP kūrimo procesas nėra toks sklandus, kaip galètų atrodyti iš ES narių ir jų partnerių pasiryžimo prisidèti prie ES krizių valdymo pajègumų kūrimo. Nors oficialusis Vašingtonas pasveikino Helsinkio nutarimus kaip žingsnį, stiprinantị tiek Europą, tiek Šiaurès Atlanto Aljansą kaip visumą, JAV administracija ị

${ }^{48}$ Lietuvos ES priskirtụ pajėgumų krepšeli sudaro po 1 mechanizuotą ir motorizuotą kuopos bei būrio dydžio pẻstininkų vienetą, karo medikų skyrių, inžinierių būrị, specialụji pajègų būrị, 1 An26 orlaivi, 2 Mi- 8 sraigtasparnius 2 išminavimo laivus, 2 karinius poligonus. 
1998 m. prasidëjusį St. Malo/ESGP kūrimo procesą iš pat pradžiu žiūrèjo gana skeptiškai ir net su tam tikru nerimu. Tuometinė JAV Valstybės sekretore M. Albright išreiškẻ nuogąstavimą, jog ESGP atskirs Europos saugumą nuo Šiaurès Amerikos saugumo, dubliuos jau esančius NATO resursus ir diskriminuos ES nepriklausančias NATO nares. Nepaisant skeptiško JAV požiūrio ị ESGP, NATO generalinis sekretorius George L. Robertson akcentavo, jog ši iniciatyva gali duoti ir pozityvu efektą - padidinti karinius Europos pajėgumus ir ịnašą tarptautiniam saugumui garantuoti.

ES dokumentuose yra aiškiai užfiksuota nuostata, jog ESGP nėra siekiama pakeisti NATO ar kurti Europos kariuomenès ${ }^{49}$, o NATO išlieka prioritetinè Europos gynybos organizacija. Institucijų ir resursų dubliavimo problema yra neišvengiama ir tam tikru požiūriu būtina. Tai ne tiek JAV ir Europos santykių, kiek pačiu europiečių tarpusavio nesusikalbẻjimo, gynybos planavimo procesų koordinavimo, fragmentuotos gynybos pramonès ir ginklavimosi politikos problema. Europos valstybės neturi jokių karinių technologijų, kurių neturètų JAV. Paradoksalu, tačiau pati ESGP idejja iš esmès yra būtent dubliuoti JAV turimus išteklius tose srityse, kuriose Europos atsilikimas yra didžiausias, t. y. strateginio oro ir jūrų transporto, satelitinès žvalgybos, taikinių nustatymo sistemų, ypatingo tikslumo ginkluotés srityse.

Diskriminacijos problema buvo susijusi su VES ijungimu ị ES struktūrą. Iki šiol šešios NATO narès - Čekija, Lenkija, Vengrija, Islandija, Norvegija ir Turkija buvo asocijuotos VES narès, tačiau sujungiant abi organizacijas ES neperèmè daugiapakopès VES narystès, todèl minètos šešios valstybès liko už borto kuriant ESGP. Salims, kurios beveik vienu metu taps tiek ES, tiek NATO narėmis, tarp jų ir Lietuvai, tokia problema nekils. Čekija, Lenkija ir Vengrija taip pat netrukus taps ES narėmis. Didžiausių problemų kyla dèl Norvegijos ir ypač Turkijos - jų galimybės prisijungti prie ES artimiausiu metu yra gana miglotos, o Turkija savo ruožtu ilgai priešinosi galimybei leisti ES (kurios nare yra Graikija) naudotis NATO pajėgumais. Tik pasiekus principinį ES sutarimą su Turkija, tapo įmanoma strateginè NATO ir ES partnerystė, kurią įtvirtino ir nemažai $2002 \mathrm{~m}$. ir $2003 \mathrm{~m}$. pasirašytų susitarimų. Jau yra sukurti nuolatiniai ES ir NATO konsultacijų ir bendradarbiavimo mechanizmai, reguliariai vyksta abiejų organizacijų susitikimai įvairiais klausimais. Pagal vadinamą Berlin Plus koncepciją ši partnerystė apima tokius pagrindinius elementus:

- ES turi priẻjimą prie NATO operacinio planavimo struktūrų;

- ES gali pasinaudoti NATO pajègumais ir ištekliais;

- DSACEUR (Sajungininkų pajègų Europoje vyriausiojo vado pavaduotojas) vadovauja ES operacijoms, kuriose naudojami NATO ištekliai;

- Adaptuojama NATO planavimo sistema, itraukiant ir ES vadovaujamas operacijas.

\footnotetext{
${ }^{49}$ Pagrindinius ESGP reglamentuojančius dokumentus galima rasti šiame rinkinyje: From St-Malo to Nice: European defence: core documents, Institute for Security Studies of EU: Chaillot Paper 47, 2001.
} 
Pirmaja tokia Berlin Plus tipo operacija tapo misija Makedonijoje, kurią ES perėmè iš NATO. Ima ryškèti ir tam tikras neformalus darbų pasidalijimas tarp NATO ir ES: NATO vykdo kolektyvinès gynybos, sudètingas kovines krizių valdymo operacijas, o ES - humanitarines, taikos palaikymo, civilinių krizių valdymo operacijas.

Vis dèlto sunku pasakyti, kaip toliau plètosis ES ir NATO santykiai. Irako krizė tik papildė vis ilgẻjantį JAV ir Europos nesutarimų sąrašą. Pastebima ir vis ryškesnè pasaulęžiūrų sankirta tarp G. Bush ir jo konservatyvios bei linkusios ị vienašališkumą aplinkos iš vienos pusès ir centro-kairès Europos šalių lyderių iš kitos pusès. Vis dèlto, perfrazuojant rašytoją Mark Twain, gandai apie transatlantinių santykių mirtį yra gerokai perdèti. Europa yra ir toliau išlieka svarbiausia JAV partnere pasaulyje kaip ir vice versa.

Kokios yra transatlantinio ryšio nedalomumo prielaidos? Pirmiausia tai nesikeičianti kai kurių Europos šalių pozicija sieti Europos saugumą su amerikiečių gynybiniais įsipareigojimais, o ne miglotais eventualiai bendros gynybos planais šios šalys, ir visu pirma Didžioji Britanija, priešintusi tokiai ESGP raidai, kuri keltu rimtą grèsmę transatlantiniam ryšiui. Tokios pozicijos laikosi naujosios NATO bei ES narès iš VRE regiono, tarp jų ir Lietuva. Šiame kontekste tvirta šių šalių parama transatlantiniam ryšiui išsaugoti gali suvaidinti gana didelị pozityvų vaidmenị. Antroji prielaida - tai strateginiai Europos išskaičiavimai: atgrasymas ir gynyba branduolinio ar kitokio plataus masto karo atveju ir didelio intensyvumo kariniai konfliktai už Europos ribų (pirmiausia Artimuosiuose Rytuose). Abiem atvejais ES išlieka ir ateity išliks priklausoma nuo JAV karinès ir politinės galios. Trečia, ypatingas paties transatlantinio ryšio pobūdis: nepaisant tam tikros trinties NATO viduje, ši institucija kartu yra ir priemonė Europos valstybėms daryti ịtaką JAV politikai. Naujoje tarptautinio saugumo aplinkoje savanoriškai atsisakyti šio ypatingo ryšio Europai būtų pavojinga. Pagaliau rugsẻjo 11 teroro aktai JAV ir karas Afganistane smarkiai paveikè Europos gynybos politikos darbotvarkę. Iki tol pagrindinè problema buvo bandymas efektyviai išvengti nereikalingo resursų dubliavimo, suderinti ESGP su NATO, o šiandien jau keliamas klausimas, kaip padaryti, kad NATO veiktų ne kaip Šiaurès Atlanto regiono gynybinė organizacija, o kaip pasaulinè jèga, kuri, reikalui esant, galètų panaudoti jègą ne tik gynybos tikslais. Tokiame kontekste ESGP galètų tapti istorine galimybe ES igyti svarbios tarptautinio saugumo veikèjos vaidmenị, pagrịstą realiais krizių valdymo pajègumais, kurių pakaktų ne tik miško gaisrui užgesinti. Galima daryti paradoksalią išvadą, jog nuo ESGP sékmés didele dalimi priklauso NATO ateitis: ESGP sėkmés atveju būtų realizuota JAV prezidento J. F Kennedy dar 1962 m. paskelbta dviejų lygių ir lygiaverčių ramsčių Atlanto Aljanso vizija, kita vertus, jeigu ESGP pasirodys besanti tik ambicinga, bet tikrovès neatitinkanti ES iliuzija, NATO ir visai Euroatlantinei saugumo bendruomenei iškiltų rimtų egzistencinių klausimų. Vienas iš jų - kam reikalinga tokia NATO, kurioje tik JAV ir Didžioji Britanija bei keletas mažesnių VRE šaliu gali veikti kartu didesnès krizès atveju, o kitos Europos šalys lieka tik pasyvios stebetojos, nepajëgiančios, nenorinčios ar negalinčios susitarti tarpusavyje ir atitinkamai investuoti į bendrą Europos saugumo ir gynybos politiką. 


\subsection{ES reforma: BUSP institucionalizacijos galimybès ir ribos}

Negatyvus chaotiško ir nekoordinuoto BUSP ịvaizdis iš dalies atsiranda dèl didelio atotrūkio tarp ES norų ir galimybių, t. y. ES galimybės yra gerokai pervertinamos, todèl keliami uždaviniai neįkandami ${ }^{50}$. Galimybes galima apibrèžti kaip tam tikrus užsienio politikos instrumentus - karinę jẻgą, diplomatiją, ekonomines priemones, kultūrinę įtaką. Svarbu ir pats veikejjo potencialas - gyventojų skaičius, teritorija, gerovés lygis, technologinis išsivystymas. Pagaliau tai ir gebejjimas priimti kolektyvinius sprendimus ir jų laikytis. Norus galima suvokti kaip tam tikrus lūkesčius, susijusius su ES globaline veikla tiek ES viduje, tiek išoreje. Tai politinis spaudimas vykdyti ES plètrą, spręsti trečiųjų šalių problemas, teikti ekonominę bei humanitarinę pagalbą, taikyti palankų prekybos režimą ir pan.

ES potencialas abejonių nekelia. ES gyvena 370 milijonų žmonių, BVP siekia 15 trilijonų dolerių (JAV atitinkamai turi 290 milijonų gyventojų ir 10 trilijonų dolerių BVP), 10 į ES pakviestų šalių turi dar apie 75 milijonų gyventojų, o norintys į ES įsilieti bulgarai, rumunai ir turkai sudarytų dar apie 100 milijonų gyventojų. Po 10 - 15 metų ES jau gali gyventi apie 550 milijonų žmonių. ES tarptautinès prekybos apimtis didžiausia pasaulyje, ji taip pat yra didžiausia humanitarinès pagalbos ir paramos ekonominei plètrai tiekèja. Kita vertus, realia politine ir diplomatine galia ES ekonominis potencialas nepavirto iki šiol. Gynybinè dimensija vystoma lètai, o ES galimybės dalyvauti valdant krizes yra glaudžiai susijusios su NATO gera valia.

Bendros pozicijos ir bendri veiksmai, matyt, yra geriausia ir realistiškiausia, ką ES, kaip vieningas galios centras, gali nuveikti pasaulyje. Teisingumo dèlei galima pasakyti, jog pavieniai bendri ES veiksmai buvo bent iš dalies sẻkmingi: Europos stabilumo paktas, Mostaro miesto administracija Bosnijoje, demokratijos įtvirtinimas Pietų Afrikoje, rinkimų monitoringas Rusijoje ir pan. Tačiau visa tai nėra aukštoji politika. Materialinè pagalba Rytų Europai ir Viduržemio jūros šalims taip pat tèra vadinamojo minkštojo saugumo projekcija. ES ekonominių sankcijų svertai yra bene stipriausias jos galios instrumentas.

Viena pagrindinių tokio atotrūkio tarp norų ir galimybių problemų yra ta, jog šalia išorinių ES interesų igyvendinimo galimybes ribojančių veiksnių egzistuoja ir rimtos institucinès kliūtys pačioje organizacijoje. Silpna užsienio ir saugumo politikos institucionalizacija yra bene didžiausia ES problema. Pirmiausia BUSP remiasi tarpvyriausybiniu principu, kuris iš esmès apriboja galimybes greitai ir efektyviai priimti sprendimus. ES, kaip organizacijos, ambicijos ịgyti didesnį svorį tarptautinèje politikoje kertasi su jos narių nenoru aukoti suvereniteto bendrų interesų labui. Principas veikti pagal konsensusą iš esmès paralyžiuoja 15 narių turinčią organizaciją ir jeigu šis mechanizmas nebus pakeistas, po kito plètros raundo ES gali apskritai

\footnotetext{
${ }^{50}$ Peterson J., Sjursen H., eds., A Common Foreign Policy for Europe?, London: Routledge, 1998, p. 19-32.
} 
nustoti priimti bendrus užsienio politikos sprendimus. Negalima atmesti galimybės, jog bus peržiūrètas ir NATO konsensuso principas atsižvelgiant ị Turkijos atveji ir išaugusį poreiki greičiau priimti politinius sprendimus krizių atvejais. ES sprendimų prièmimą šiek tiek sustiprino Amsterdamo sutarties nuostata, jog ES bendriems veiksmams ir pozicijoms yra taikoma konstruktyvaus susilaikymo teisè.

Institucinis BUSP silpnumas labiausiai išryškejja ji lyginant su ES ekonomine ir pinigų sajunga. Šioje srityje egzistuoja aiškūs bendri ekonominiai interesai tiek dèl bendrosios rinkos, tiek ekonominiuose vis-a-vis santykiuose su išoriniu pasauliu, kuriuos užtikrina stipri viršnacionalinė institucija - EK, turinti pakankamai svertu priversti paklusti jos sprendimų nepaisančius narius. BUSP srityje nieko panašaus nėra. Pagaliau nelabai aiški ir politinės integracijos nauda visoms narèms, kuri būtu analogiška ekonominei naudai: vien ES prestižas ir globalinė galia gali būti nepakankami stimulai bendrai užsienio ir saugumo politikai atsirasti. Greičiausiai tam reikalingas stiprus išorinis postūmis ar net sukrètimas, kuris prilygtų Sovietų Sajungos grèsmei, ar panašus išorinis konsoliduojantis veiksnys. Galbūt tokiu konsoliduojančiu veiksniu ilgainiui galètų tapti augantis tarptautinio terorizmo pavojus.

1997 m. Amsterdamo sutartimi buvo pabandyta suteikti svaresnị institucinị pagrindą BUSP - buvo numatytas VES funkcijų perdavimas ES. Vis dèlto neefektyvios organizacijos ịjungimas į kitą neefektyvią instituciją (t. y. BUSP) negali sukurti vieno efektyvaus junginio.

Pagaliau išlieka neišspręstas ir BUSP finansavimo klausimas. Kad ES galètų sukurti savarankišką saugumo ir gynybos dimensiją, reikètų 4-7\% ES biudžeto, o tai yra nerealu, turint omeny, kad daugelis ES narių išleidžia mažiau nei $2 \%$ savo BVP gynybai ir dar labiau mažina karines išlaidas. Tik BUSP administracinès išlaidos dengiamos iš ES biudžeto (nesiekia net $1 \%$ ), o operacines išlaidas dengia valstybès pagal norus ir galimybes, t. y. ad hoc būdu.

Kai kurias iš minètų problemų gali išspręsti būsima ES Konstitucija: jos projekte numatoma išplèsti ESGP apimtị, sustiprinti didžiujų valstybių vaidmeni joje, igalinti to norinčias valstybes sudaryti laikinas koalicijas veikti ES vardu. Konstitucineje sutartyje taip pat užsimenama apie gana ribotą vyriausybių demokratinę atsakomybę už veiksmus igyvendinant bendrają saugumo ir gynybos politiką.

Svarbūs pasikeitimai Konstitucinès sutarties projekte numatomi Europos Tarybos sprendimų prièmimo procedūrose plačiau taikant kvalifikuotos daugumos sprendimų prièmimo principą. Tiesa, kvalifikuotos daugumos sprendimams bus reikalinga ne tik daugumos valstybių pritarimas, bet ir tai, kad jos atstovautų ne mažiau kaip $60 \%$ ES piliečių. Gerokai daugiau galių negu dabartinis Aukštasis bendrosios užsienio ir saugumo politikos atstovas turètų igyti ir naują Europos Sajungos užsienio reikalų ministro postą užimsiantis pareigūnas, kuris kartu bus ir EK pirmininko pavaduotojas. Jis atstovaus ES interesams tiek BUSP, tiek ESGP klausimais.

Projektas numato ir Petersbergo užduočių išplètimą: ES neturètų apsiriboti krizių valdymu ir taikos palaikymu, bet ir vykdyti jungtines nuginklavimo operacijas bei kovą su terorizmu, taip pat paramą trečiosioms šalims kovojant su vidaus terorizmu. Konstitucinės sutarties projekte atsiradusi sąvoka ,struktūrizuotas bendradarbiavimas" igalina atskiras valstybes burtis ị glaudesnio bendradarbiavimo grupes nustatant kriterijus, pagal kuriuos kitos valstybès galètų prie jų prisijungti. Atskiruo- 
se straipsniuose numatoma, kad ES Taryba tokiai šalių grupei gali pavesti vykdyti tam tikras, įskaitant ir karines, operacijas saugumo ir gynybos srityje veikiant ES vardu. Šių operacijų planavimas ir vykdymas turètų vykti bendradarbiaujant su ES užsienio reikalų ministru. Konstitucinès sutarties projektas taip pat numato galimybę pereiti prie bendros gynybos, kuri praktiškai atitiktų Šiaurẻs Atlanto sutarties penktajį straipsnị, jeigu ES viršūnių taryba priimtų tokị sprendimą. Konstitucijoje įtvirtinta ir solidarumo - visapusiškos pagalbos - sąlyga, jeigu viena iš valstybių nariu taptų teroristinio išpuolio auka. Siekiant stiprinti ES gynybos pajègas numatoma ịkurti Europos ginkluotės, mokslinių tyrimų ir karinių pajègumų agentūrą.

Numatomi pasikeitimai formuojant ir iggvendinant BUSP turètų padidinti jų efektyvumą ir sustiprinti ES vaidmenị tarptautineje politikoje. Suprantama, kad išsiplètusi iki 25 narių (ateityje gali būti ir daugiau) ES vargu ar galès vienbalsiškumo principu priimti nepavèluotus ir efektyvius sprendimus įvairiais, tarp jų ir BUSP, klausimais. Tačiau kartu negalima pamiršti, kad užsienio, o tuo labiau saugumo ir gynybos politika yra valstybiu prestižo ir savarankiškumo tarptautineje sistemoje išraiška ir né viena valstybè, nepriklausomai nuo jos dydžio, nenori taip lengvai jos atsisakyti. Kitas aktualus klausimas - atsakomybe už priimtus sprendimus ir jų iggvendinimo pasekmes. Demokratijos ir viešumo trūkumas ES valdymo struktūrose bei priimant sprendimus - sena ir aktuali problema. Konstitucijos projekte nenumatoma, kad europarlamentas ar nacionaliniai parlamentai galètų efektyviai kontroliuoti ES Tarybos ir Komisijos priimamus sprendimus ir jų igyvendinimą . Jie galès gauti informaciją apie vykstančius procesus, o reali valdžia bus sutelkta ES ir jos valstybių-narių vykdomosios valdžios institucijų rankose.

Ar sėkmingai pavyks igyvendinti būsimos ES Konstitucinès sutarties nuostatas BUSP ir ESGP, parodys netolima ateitis. Tačiau jau dabar yra būtina analizuoti ir vertinti galimas tokios politikos igyvendinimo galimybes ir pasekmes Lietuvai, nes ne visada ir ne visi BUSP sprendimai gali atitikti jos interesus. Kai kurių ES Konstitucinès sutarties projekto nuostatų galima įtaka Lietuvai aptariama 3 lentelèje. 
3 lentelè: ES Konstitucijos poveikis Lietuvos užsienio ir saugumo politikai

\begin{tabular}{|c|c|}
\hline $\begin{array}{c}\text { ES KONSTITUCIJOS PROJEKTO } \\
\text { NUOSTATA }\end{array}$ & GALIMAS POVEIKIS LIETUVAI \\
\hline $\begin{array}{c}\text { ES Užsienio reikalụ ministro pareigybès } \\
\text { įsteigimas }\end{array}$ & $\begin{array}{l}\text { Didesnė BUSP reikalų koordinacija yra sveikintinas } \\
\text { reiškinys. Lietuva taip pat kaip ir kitos šalys galés } \\
\text { efektyviau koordinuoti savo užsienio politika su EK. }\end{array}$ \\
\hline Kvalifikuotos daugumos balsavimo principai & $\begin{array}{l}\text { Lankstesnis balsavimas BUSP igyvendinimo } \\
\text { klausimais neigiamos itakos Lietuvai neturẻs. } \\
\text { Svarbiausi BUSP politiniai ir kariniai sprendimai ir } \\
\text { toliau bus priimami vienbalsiškai, - tai garantuos } \\
\text { Lietuvai galimybę apsaugoti savo nacionalinius } \\
\text { interesus. Kitais atvejais, esant reikalui, Lietuva galès } \\
\text { naudotis konstruktyvaus susilaikymo teise, } \\
\text { nestabdančia ES veiksmų. ESGP srityje toliau bus } \\
\text { taikomas vienbalsiškumo principas. }\end{array}$ \\
\hline \begin{tabular}{|l|}
\multicolumn{1}{|c|}{ Papildyti Petersbergo uždaviniai } \\
ES gali panaudoti karines ir civilines priemones \\
tokioms operacijoms vykdyti: \\
$\quad$-jungtines nuginklavimo; \\
-humanitarines ir gelbejjimo; \\
-karinés pagalbos trečiosioms šalims; \\
-konfliktų prevencijos ir taikos palaikymo; \\
-krizių valdymo, taip pat ir taikos ivedimo; \\
-pokonfliktinés stabilizacijos. \\
\end{tabular} & $\begin{array}{l}\text { Jei ES imsis platesnio spektro užduočiu - nuo } \\
\text { humanitarinių iki kovinių misijų, kaip tai numato } \\
\text { Konstitucijos projektas, - padidès ir reikalavimai ES } \\
\text { pajėgumams. Ilgainiui ir Lietuvai gali tekti peržiūrèti } \\
\text { ES priskiriamy̨ pajėgų krepšeli. }\end{array}$ \\
\hline \begin{tabular}{|l|}
\multicolumn{1}{|c|}{ Europos ginkluotès, mokslinių tyrimų ir } \\
$\quad$ karinių pajègumų agentūra \\
,', steigiama agentüra, kurios tikslas - nustatyti \\
operaciju vykdymo poreikius, skatinti priemones \\
siems poreikiams tenkinti, padèti nustatyti ir, tam \\
tikrais atvejais, igyvendinti bet kokiqpriemone, \\
bütinapramoninei ir technologinei gynybos \\
sektoriaus bazei stiprinti, dalyvauti formuojant \\
Europos pajegumu ir ginkluotess politikq."
\end{tabular} & 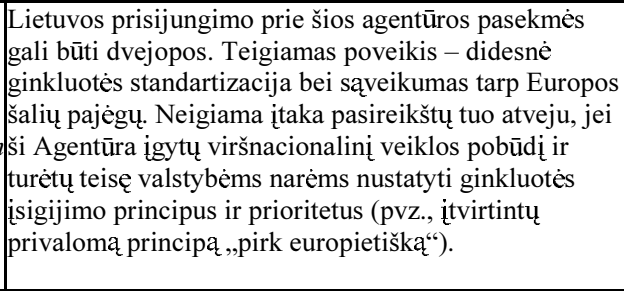 \\
\hline
\end{tabular}

Galima apibendrinti, jog ES Konstitucija, jeigu ją patvirtins Tarpvyriausybinė konferencija, itin neigiamų pasekmių saugumo ir užsienio politikos srityje Lietuvai neturès. Daugelis nuostatų, skirtų padidinti sprendimų prièmimo efektyvumą ir politikos koordinavimą, gali būti vertinamos tik teigiamai. Bene jautriausias klausimas Lietuvai yra būsimas ESGP santykis su NATO struktūromis ir funkcijomis.

\section{Išvados}

Neapibrèžtas Europos identitetas, didžiulè interesų įvairovè ir silpna institucionalizacija yra tie trys pagrindiniai veiksniai, kurie iki šiol kliude pasiekti didesni ES vaidmeni pasaulio politikoje. Nei po Maastrichto, nei po Amsterdamo sutarties BUSP nepadare ES svarbesniu tarptautiniu veikëju, o po naujo plètros raundo BUSP efektyvumas gali ir dar labiau sumažèti, jeigu nebus imtasi esminių institucinių reformų, kurios numatomos Konvento dèl Europos ateities parengtame ES Konstitucijos projekte. Kita vertus, vargu ar institucinė ES reforma išspręstų kur kas fundamenta- 
lesnius ES vaidmenị pasaulyje lemiančius klausimus - Europos identiteto ir bendrų interesų problemą. Europos identitetas negali būti primestas iš viršaus, bet turi kilti iš apačios - t. y. turi stiprèti paprastų ES gyventojų europietiškumo jausmas, kuris galiausiai sudarytų prielaidas nacionalinèms vyriausybėms atsisakyti savo ambiciju bendrų Europos interesų labui. Europos Komisija negali primesti narèms neva bendrų tikslų, jeigu jos pačios to nenorès ir neleis.

ES viduje federalizmo idejjos tebèra gajos ir niekur nedings, tačiau išlieka struktūrinè problema: norint ịvykdyti kai kurių valstybių siekius suteikti ES didesnị vaidmeni BUSP srityje, reikia didinti sprendimų priëmimo proceso lankstumą, o didesnis lankstumas neišvengiamai kertasi su nacionalinių interesų pirmenybės užsienio ir saugumo politikos srityje principu, kurio laikosi didžiosios valstybès. Taigi federalinès Europos ateities klausimas iš esmès yra nacionalinių užsienio politikų konvergencijos, arba didesnio bendrojo vardiklio, klausimas. Tikètis, kad jis bus išspręstas artimiausiais metais, vargu ar galima.

Kokia vis dèlto yra ES vieta pasaulio politikoje šiandien ir kokias funkcijas ES bando prisiimti ir atlikti pasaulyje? ES neužpildè tos politinès ir karinès galios vakuumo, kurị pasaulyje paliko Sovietų Sajungos žlugimas. ES iki šiol nèra lygiavertė JAV partnere palaikant tarptautinị saugumą ir netgi nesugeba viena susitvarkyti savo kontinente. Bandymai tarpininkauti taikos procesui Artimuosiuose rytuose, Balkanuose, Korejoje nebuvo ir nèra sèkmingi. Kita vertus, ES šalys vis aktyviau reiškiasi taikos palaikymo misijose: Balkanuose ir Afganistane daugiausia taikdarių yra būtent iš Europos, ES pirmą kartą perémé iš NATO misiją Makedonijoje, pradèjo sudètingą savarankišką operaciją Kongo Demokratinèje Respublikoje. Dèl ịvairaus lygio ir formų dialogų ES jau seniai yra tapusi savotišku tiltu tarp turtingų ir vargšų, Šiaurès ir Pietų, taigi atlieka itin pozityvų vaidmenį stiprinant pasaulio stabilumą. Pagaliau ES yra aktyvi pasaulinės ekonomikos prižiūrètoja, efektyviai dalyvaujanti PPO sistemoje.

Lietuvos ịsijungimo į Euroatlantines institucijas - ES ir NATO - procesas sutampa su didelių pokyčiu šių institucijų vidinèje struktūroje ir veikloje procesais. Lietuva ịsilieja ị kokybiškai skirtingas organizacijas, negu jos buvo prieš 10 metų. Baigiasi laikotarpis, kai Lietuva galëjo prisijungti prie vieno ar kito ES demaršo BUSP srityje, tačiau tiesiogiai nedalyvauti ji igyvendinant ir faktiškai už ji neatsakyti. Irako krizès metu Lietuvai jau teko labai stipriai pajusti, jog senosios ES narès iš būsimų narių tikèsis solidarumo svarbiausiais užsienio ir saugumo politikos klausimais. Be abejonès, ateityje BUSP įtaka Lietuvai tik didės. Kiek ši įtaka bus teigiama, priklausys nuo to, kokiu keliu pasuks pati Europa - savarankiškos gynybinès struktūros, kaip alternatyvos NATO, kūrimo ar glaudžios strateginès partnerystės su JAV ir NATO plètojimo keliu. Bet kokiu atveju jau dabar aišku, jog Lietuvai reikès nuolat ieškoti balanso tarp įsipareigojimų ES ir įsipareigojimų NATO. Šiame procese Lietuvai vertingiausi bus ne tiek kariniai pajëgumai ir ekonomikos augimo tempai, bet diplomatiniai sugebejjimai.

Šiandien vargu ar galima kalbėti apie kokį nors ES bandymą atsverti JAV globalinę karinę galią. Matyt, galima kalbẻti apie Europą kaip tam tikrą politinę, norminę ir net vertybinę alternatyvą JAV dominavimui pasaulyje. Europa dar neišsèmé savo potencialo ir ne laikas kalbèti apie jos dinozaurejjimą. Maastrichto sutarčiai dar tik 12 metų, o integracijos fenomenas yra sunkiai paaiškinamas, bet galingas reiškinys. Lieka tikètis, kad transatlantinių santykių atžvilgiu šis potencialas nebus panaudotas destruktyviems tikslams. 